\title{
Structural history of the Arthur Lineament, northwest Tasmania: an analysis of critical outcrops
}

\author{
O. H. HOLM* AND R. F. BERRY
}

Centre for Ore Deposit Research, University of Tasmania, Tas. 7005, Australia.

\begin{abstract}
The Arthur Lineament of northwestern Tasmania is a Cambrian ( $510 \pm 10 \mathrm{Ma}$ ) high-strain metamorphic belt. In the south it is composed of metasedimentary and mafic meta-igneous lithologies of the 'eastern' Ahrberg Group, Bowry Formation and a high-strain part of the Oonah Formation. Regionally, the lineament separates the Rocky Cape Group correlates and 'western' Ahrberg Group to its west from the relatively low-strain parts of the Oonah Formation, and the correlated Burnie Formation, to its east. Early folding and thrusting caused emplacement of the allochthonous Bowry Formation, which is interpreted to occur as a fault-bound slice, towards the eastern margin of the parautochthonous 'eastern' Ahrberg Group metasediments. The early stages of formation of the Arthur Lineament involved two folding events. The first deformation ( $\left.\mathrm{CaD}_{1}\right)$ produced a schistose axial-planar fabric and isoclinal folds synchronous with thrusting. The second deformation $\left(\mathrm{CaD}_{2}\right)$ produced a coarser schistosity and tight to isoclinal folds. South-plunging, north-south stretching lineations, top to the south shear sense indicators, and south-verging, downward-facing folds in the Arthur Lineament suggest south-directed transport. $\mathrm{CaF}_{1}$ and $\mathrm{CaF}_{2}$ were rotated to a north-south trend in zones of high strain during the $\mathrm{CaD}_{2}$ event. $\mathrm{CaD}_{3}$, later in the Cambrian, folded the earlier foliations in the Arthur Lineament and produced west-dipping steep thrusts, creating the linear expression of the structure.
\end{abstract}

KEY WORDS: Arthur Lineament, Cambrian, strain, structure, Tasmania, Tyennan Orogeny.

\section{INTRODUCTION}

The Arthur Lineament, northwest Tasmania, is $8 \mathrm{~km}$ wide, $110 \mathrm{~km}$ long and northeast-trending. It is a sheared belt of metamorphic rocks (Gee 1967a) of Cambrian age (Turner et al. 1998). The lineament separates the weakly deformed Neoproterozoic Rocky Cape Group correlates (shelf siliciclastics) to the northwest from the low-strain Burnie and Oonah Formations (turbidites) to the east (Figure 1). The lineament was multiply deformed during the Middle to Late Cambrian, Tyennan Orogeny $\left(\mathrm{CaD_{1- }}\right.$ $C a \mathrm{D}_{3}$ ) and has subsequently undergone several episodes of minor deformation in the Middle Devonian $\left(D e \mathrm{D}_{1}, D e \mathrm{D}_{4}\right)$. The aim of this study is to use detailed structural information from parts of the Arthur Lineament to determine the nature of Cambrian tectonism in northwestern Tasmania.

The Arthur Lineament has been the focus of several previous workers, at varying levels of detail. Gee (1967b) and Gee et al. (1967) carried out detailed structural mapping of the north coast of Tasmania, including the Somerset Doctors Rocks area. Spry (1957a) and Turner et al. (1991) carried out regional mapping in the lower Pieman River and Corinna areas, but did not attempt a detailed structural analysis. The present work is based on regional mapping of the Arthur Lineament and surroundings, but concentrating on detailed structural studies of the Somerset Doctors Rocks region (northern study area), and the Reece Dam and spillway, Mt Donaldson-Longback and Granville Harbour to Four Mile Beach regions (southern study area) (Figures 1, 2). The character of the rocks and structural deformation in the Arthur Lineament between the northern and southern study areas has not been investigated. The structural events described below are based on a synthesis of data from all these areas. The cleavage nomenclature of Passchier and Trouw (1996) is used in the descriptions below.

Rock units exposed within the southern part of the Arthur Lineament include the 'Timbs Group' and the Oonah Formation (Figure 2). The term 'Timbs Group' was first used by Turner etal. (1991), but was not formally defined: furthermore the 'Timbs Group' is not a viable stratigraphic unit. It was interpreted to be a correlative of the Neoproterozoic Togari and Ahrberg Groups in northwest Tasmania, based on its similar stratigraphy and identical chemistry to the tholeiitic mafic sequences (Crawford 1992; Turner \& Crawford 1993). However, the 'Timbs Group' (Turner et al. 1991) includes the Bowry Formation. Unlike the rest of the 'Timbs Group', amphibolites in the Bowry Formation contain relict glaucophane, indicating an early blueschist metamorphic history (Turner \& Bottrill 2001). This is not seen elsewhere in the 'Timbs Group'. Furthermore the Bowry Formation contains a $777 \pm 7 \mathrm{Ma}$ granitoid. Granitoids of this age are unknown elsewhere on mainland Tasmania. The age for the base of the Togari Group is $<750 \mathrm{Ma}$ (Calver \& Walter 2000). The Bowry

*Corresponding author and present address: Geoscience Australia, GPO Box 378, Canberra, ACT 2601, Australia (Oliver.Holm@ga.gov.au). 
Formation amphibolites, which the granitoid intrudes, have been correlated with the Kanunnah Subgroup, which has a preferred age of $650-580 \mathrm{Ma}$ (Crawford 1992). We conclude that the Bowry Formation cannot be a lithostratigraphic correlative of the Kanunnah Subgroup or any part of the Ahrberg Group. Turner and Bottrill (2001) discussed the problems associated with large differences in metamorphic history between the Bowry Formation and other parts of the 'Timbs Group' and concluded that the Bowry Formation had a faulted margin against the remainder of the 'Timbs Group', with a metamorphic grade difference across the fault. The western section of the 'Timbs Group' is interpreted here as a parautochthonous slice of the Ahrberg Group, and is referred to in this paper as the 'eastern' Ahrberg Group. The autochthonous Ahrberg Group is referred to as the 'western' Ahrberg Group. The Bowry Formation is referred to here as a separate unit with no specific correlates. The Bowry Formation is fault bounded in the southern Arthur Lineament, has internal evidence of a different metamorphic history (Turner \& Bottrill 2001) and is probably much older There are other fault-bounded units within the Arthur Lineament, in particular, east of the Bowry Formation and faulted against the high-strain Oonah Formation is a block of material that is similar in appearance to the 'eastern' Ahrberg Group, but no definite correlation can be made at this time.

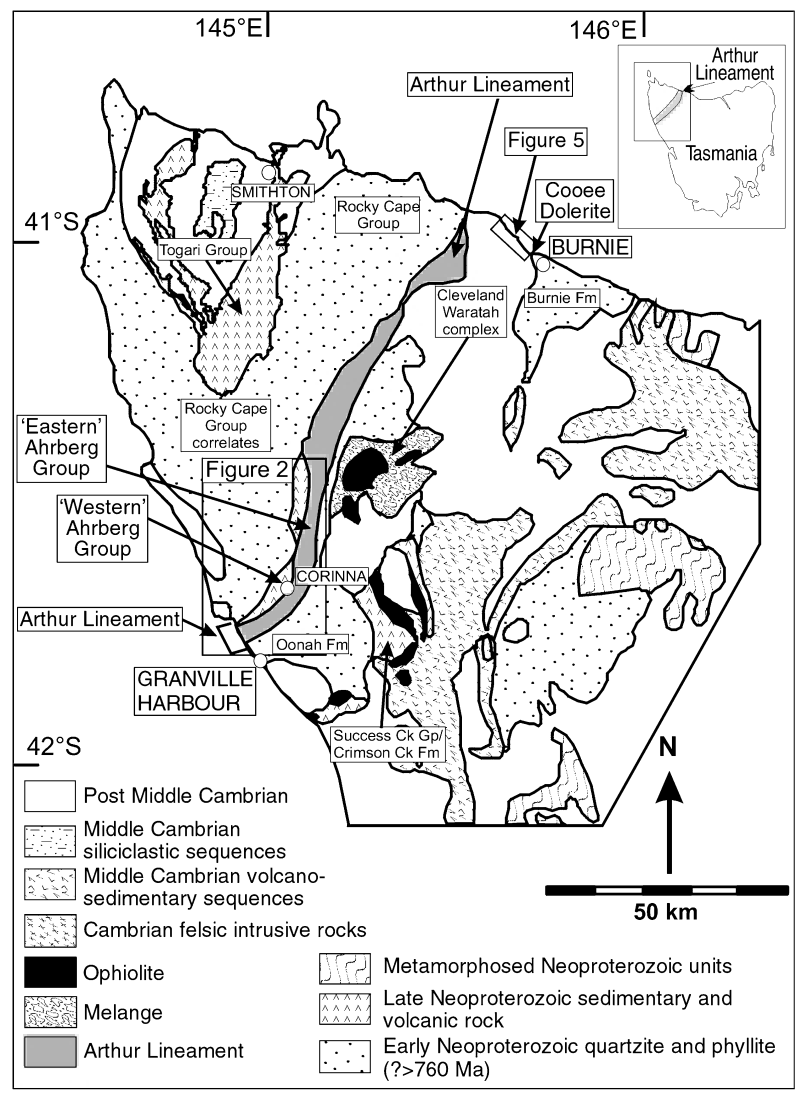

Figure 1 Setting of the Arthur Lineament, northwest Tasmania (modified after Brown et al. 1995). The Arthur Lineament consists of the high strain (metamorphosed) Burnie and Oonah Form ations, the 'eastern' Ahrberg Group, the Bowry Formation and other uncorrelated fault-bounded units.
The western boundary of the lineament in the north was defined by Gee (1967a) as a gradation from unmetamorphosed Rocky Cape Group outside the lineament, to slates and phyllites within it. In this area, Gee (1967a) also recognised a 'mineral' isograd, defined by the appearance of albite porphyroblasts. Turner (1989) described the southeastern boundary of the lineament, noting the transition from poorly cleaved quartzite and slaty pelite outside the lineament, to schist and phyllite that is accompanied by metamorphic differentiation within the lineament. However, as yet, no change in metamorphic grade has been recognised at the eastern boundary of the lineament, possibly due to the simple mineral assemblage in the psammite-dominated packages. At the boundaries of the Arthur Lineament, early folds become tighter and quartz veining is more abundant. The features that define the boundary are dominated by dynamic metamorphic gradients and to emphasise this we refer to the 'unmetamorphosed' rocks as low-strain (slaty) zones and to the 'metamorphosed' rocks as high-strain (phyllitic or schistose) zones. On the north coast, the eastern margin of the lineament was recognised near Doctors Rocks and is not hidden under cover as suggested by Gee (1967a).

\section{REGIONAL GEOLOGY}

The Early to Middle Neoproterozoic of northwest Tasmania was dominated by deposition of shallow-water siliciclastics and siltstone (Rocky Cape Group and correlatives) in the west and turbidites (Burnie and Oonah Formations) in the east (Spry 1964). An extensional phase followed in the Late Neoproterozoic ca 650-550 Ma (Adams et al. 1985; Calver \& Walter 2000). This featured widespread intrusion of tholeiitic dolerite dykes (Rocky Cape dyke swarm), extrusion of tholeiitic basalts and deposition of associated volcanogenic sediments, carbonates and shallow-marine siliciclastics (Success Creek Group - Crimson Creek Formation, Togari and Ahrberg Groups) (Brown 1989; Turner 1989; Crawford \& Berry 1992). The Togari and 'western' Ahrberg Groups rest on a regional-scale low-angle unconformity. A more intense deformation (Wickham Orogeny) is known from King Island where there was polyphase deformation and extensive granitoid intrusion at approximately $760 \mathrm{Ma}$ (Cox 1989; Turner et al. 1998), which may correlate with the unconformity beneath the Upper Neoproterozoic sequences of northwest Tasmania.

An arc-continent collision in the Early to Middle Cambrian initiated the Tyennan Orogeny $(510 \pm 10 \mathrm{Ma})$ (Berry \& Crawford 1988; Crawford \& Berry 1992; Turner et al. 1998). This resulted in the emplacement of allochthons, including mafic-ultramafic complexes in western and northern Tasmania (Crawford \& Berry 1992; Turner et al. 1998). Movement indicators from the mylonitic soles of the allochthonous mafic-ultramafic complexes indicate west-directed obduction, the regional synthesis inferring an east-dipping subduction zone (Berry \& Crawford 1988). The Arthur Lineament was formed during the early stages of the Tyennan Orogeny and pre-dates a Middle Cambrian unconformity (Turner et al. 1998), but the exact process of its formation remains in doubt (Turner 1989; Berry 1994). 
Subsequent deformation in the Middle Devonian, as part of the Tabberabberan Orogeny (ca $370 \mathrm{Ma}$ ), resulted in further faulting and dome-and-basin style folding. This was closely followed by granitoid intrusion (367-332 Ma) (Williams et al. 1989).

\section{REGIONAL STRUCTURAL HISTORY OF THE ARTHUR LINEAMENT}

In both the northern and the southern areas of the Arthur Lineament, two intense, early fabrics are recognised. These fabrics decrease in intensity away from the lineament (Figure 3a, b). There is clear, consistent and widespread evidence for the relative timing of the $C a \mathrm{D}_{1}$ and $C a \mathrm{D}_{2}$ events. The existing data (Turner et al. 1998) suggest that both geometric events occur very early in the Tyennan Orogeny. They have very similar spatial distribution. We argue that there is a close genetic link between these events and that they can be correlated throughout the length of the lineament.

A $\mathrm{D}_{3}$ event was recognised in the northern Arthur Lineament. It has produced a weak, subvertical cleavage, with a north-northeast strike, in pelitic layers. $\mathrm{F}_{3}$ macroscale, open folds pre-date deformation interpreted to be
Devonian in age. $\mathrm{A}_{3}$ event is also present in the southern parts of the Arthur Lineament. It also produced a variably developed, upright to west-dipping, north-northeaststriking cleavage, of similar intensity to the $S_{3}$ fabric in the north of the Arthur Lineament. In the southern area the $\mathrm{D}_{3}$ event is Late Cambrian in age, constrained by overprinting relationships at the Reece Dam spillway, where the $\mathrm{D}_{3}$ refolds the earlier fabrics, and on the west coast, north of Granville Harbour, where the $\mathrm{S}_{3}$ does not penetrate the overlying Ordovician sedimentary rocks. In the Balfour and Trowutta areas, to the west of the Arthur Lineament, a fabric with consistent style and orientation, related to folding interpreted here to be Late Cambrian in age, is widely developed (Everard et al. 1996). On these grounds the $\mathrm{D}_{3}$ event in both areas is considered to be the same event.

\section{Deformation $\mathrm{CaD}_{1}$ and $\mathrm{CaD}_{2}$}

A $C a \mathrm{D}_{1}$ event is evident throughout the Arthur Lineament. $\mathrm{Ca} \mathrm{D}_{1}$ produced mesoscopic to macroscopic, gently inclined to recumbent, isoclinal folds $\left(\mathrm{CaF_{1 }}\right)$, and a finely spaced to schistose $\mathrm{S}_{0}$-parallel axial planar foliation $(\mathrm{CaS})$. To the east of the lineament, in $C a \mathrm{D}_{1}$ low-strain zones, $C a \mathrm{~S}_{1}$ is finely spaced to phyllitic and is best developed in more pelitic layers. The cleavage is typically a smooth, $0.5 \mathrm{~mm}$

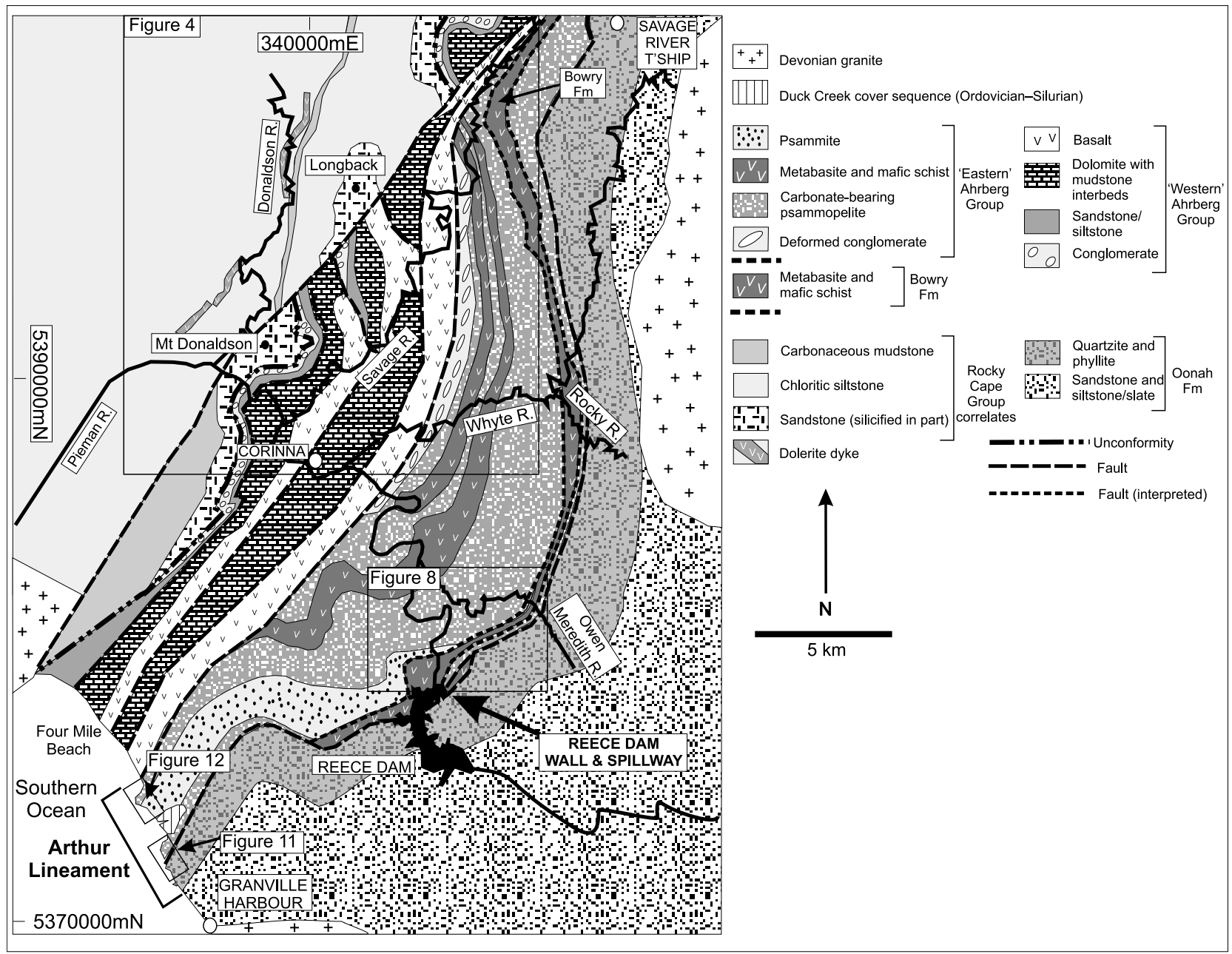

Figure 2 Simplified geological map of the southern Arthur Lineament (modified after Turner et al. 1991). See Figure 1 for location. 

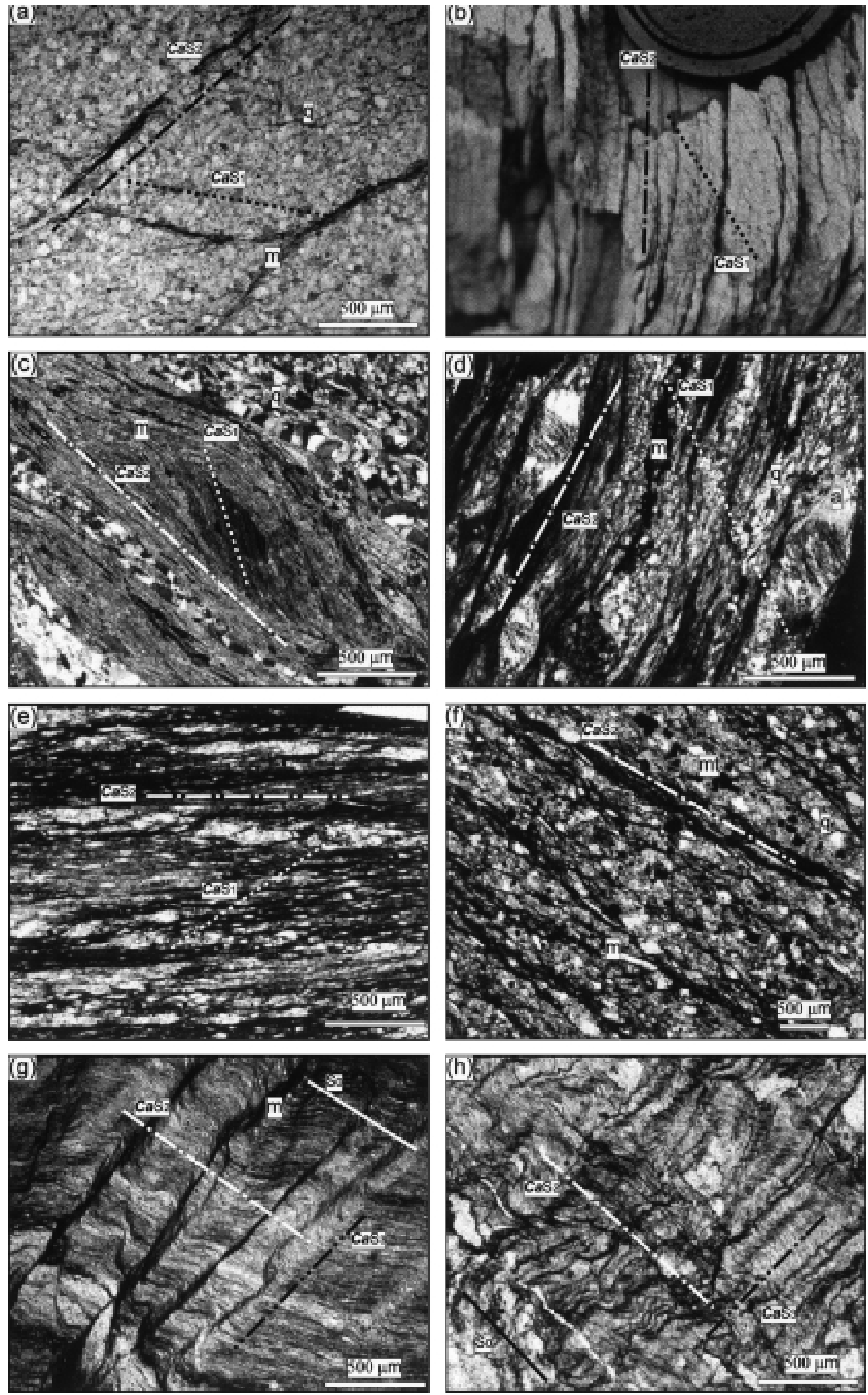
spaced, parallel cleavage, with discrete cleavage domains and microlithons. In the southern study area, in the lowstrain zone $3-5 \mathrm{~km}$ east of the lineament, the $\mathrm{CaS}_{1}$ foliation dips steeply to the northwest, whereas $C a \mathrm{~L}_{01}$ intersection lineations plunge moderately to steeply to the northeast. Approximately $1-3 \mathrm{~km}$ east of the lineament, where the strain levels are slightly higher (zones of phyllitic $\mathrm{CaS}_{1}$ are dominant) the $\mathrm{CaS}$ foliation dips moderately to the northeast, whereas $C a \mathrm{~L}_{01}$ intersection lineations plunge gently to moderately to the northeast. In zones of high strain within the lineament, $C a S_{1}$ is a smooth, zonal schistosity with finely spaced parallel cleavage domains (0.02-0.2 mm wide microlithons), and discrete transitions between cleavage domains and microlithons. Within the lineament, $C a \mathrm{~S}_{1}$ is preserved in $\mathrm{CaS}_{2}$-parallel lenses of mica and chlorite (Figure $3 \mathrm{c}$ ). In syn- $\mathrm{CaD}$ albite porphyroblasts, inclusion trails $\left(\mathrm{S}_{\mathrm{i}}\right)$ interpreted to be relict $C a \mathrm{~S}_{1}$ are preserved (Figure $3 \mathrm{~d}$ ). $C a \mathrm{D}_{1}$ high-strain zones feature intensely developed $\mathrm{CaS}_{1}$ and are dominated by $\mathrm{CaF}$ folds and $\mathrm{S}_{0}$-parallel, syn- $C a \mathrm{D}_{1}$ thrust faults. In these areas $\mathrm{CaS}_{1}$-parallel quartz segregations are common. $\mathrm{CaL} \mathrm{L}_{01}$ intersection lineations and $C a \mathrm{~L}_{1}$ stretching lineations are common and plunge moderately to the south-southwest.

$\mathrm{Ca} \mathrm{D}_{2}$ structures are pervasive throughout the lineament and to the east. $C a \mathrm{D}_{2}$ produced recumbent, tight to isoclinal folds $\left(C a \mathrm{~F}_{2}\right)$. On the north coast, in $\mathrm{Ca \textrm {D } _ { 2 }}$ low-strain areas to the east of the lineament, $C a \mathrm{~F}_{2}$ folds plunge gently to the east and west, with axial planes dipping gently south. However, in the south, 3-7 km from the lineament, $C a \mathrm{~F}_{2}$ folds plunge moderately to the northeast and $\mathrm{CaS} \mathrm{S}_{2}$ dips moderately to steeply to the east. In both of these areas the deformation produced a smooth, parallel, 3-8 $\mathrm{mm}$ spaced, axial planar cleavage in sandstone with discrete transitions between cleavage domains and microlithons $\left(\mathrm{CaS}_{2}\right)$. More proximal to the lineament $(1-3 \mathrm{~km}$ to the east of the linea-

Figure $3 \mathrm{CaS}_{1}, \mathrm{CaS}_{2}$ and $\mathrm{CaS}$, in and near the Arthur Lineament. (a) Weakly developed, slaty $\mathrm{CaS}_{2}$ crenulating weakly developed $\mathrm{CaS}_{1}$ : Burnie Formation sandstone (plane-polarised light), sample 147586 (399790 mE, $5457060 \mathrm{mN}$ ). (b) Weakly developed, slaty $\mathrm{Ca} \mathrm{S}_{2}$ crenulating weakly developed $\mathrm{Ca} \mathrm{S}_{1}$ : Oonah Formation sandstone, (lens cap is $50 \mathrm{~mm}$ diameter) $(353830 \mathrm{mE}, 5380140 \mathrm{mN}$ ). (c) Strongly developed schistose $\mathrm{CaS}_{2}$ enveloping $\mathrm{CaS}_{1}$ : basal unit of 'eastern' Ahrberg Group (cross-polarised light), sample 147587 (345240 mE, $5392040 \mathrm{mN}$ ). (d) Strongly developed schistose $\mathrm{CaS}$ and syn- $\mathrm{CaS}$ albite porphyroblasts with oblique $\mathrm{CaS}$, preserved as $\mathrm{Si}$ in albite: correlative of Ahrberg Group, to the east of the Bowry Formation (cross-polarised light), sample 147588 (350180 mE, $5388100 \mathrm{mN}$ ). (e) Phyllitic metasiltstone, showing syn- $\mathrm{Ca} \mathrm{S}_{2}$ boudinage of coarse-grained layers and possible relicts of $\mathrm{CaS}_{1}$, oblique to the main foliation $\left(\mathrm{CaS} \mathrm{S}_{2}\right)$ : Burnie Formation, Domain N3 (plane-polarised light), sample 33309 (398450 mE, $5458200 \mathrm{mN}$ ). (f) Phyllitic metasiltstone, with $\mathrm{CaS}_{2}$ developed subparallel to $\mathrm{S}_{0}$; no evidence of $C a \mathrm{~S}_{1}$ was found: 'western' Ahrberg Group, $300 \mathrm{~m}$ west of boundary-fault with 'eastern' Ahrberg Group (cross-polarised light), sample 147589 (344530 mE, $5392100 \mathrm{mN}$ ). (g) Finely spaced, So-parallel $\mathrm{CaS}$, evident in mudstone beds and crenulated by spaced $\mathrm{Ca} \mathrm{S}_{3}$ : Rocky Cape Group correlative beds (plane-polarised light), sample 147590 (343860 mE, $5401800 \mathrm{mN}$ ). (h) Finely spaced, So-parallel $\mathrm{CaS}$, crenulated by spaced $\mathrm{CaS}_{3}$ : Rocky Cape Group correlative beds (plane-polarised light), sample 147591 (339200 mE, $5394155 \mathrm{mN}$ ). m, white mica; a, albite; q, quartz; mt, magnetite. Samples numbers refer to the University of Tasmania rock catalogue. ment), $\mathrm{CaS}_{2}$ is a smooth, $2-3 \mathrm{~mm}$ spaced, parallel, phyllitic cleavage with discrete transitions between cleavage domains and microlithons (Figure 3e). Regionally, $\mathrm{CaS}_{2}$ is the dominant foliation in both pelitic and psammitic layering. Within the lineament, in zones of high $C a \mathrm{D}_{2}$ strain, $\mathrm{CaS}_{2}$ is a smooth, $0.5-1.5 \mathrm{~mm}$ spaced, parallel schistosity with discrete cleavage domains and microlithons. It is subparallel to $\mathrm{S}_{0}$ and axial planar to tight to isoclinal folds. Crenulated $\mathrm{CaS}_{1}$ is preserved in $\mathrm{CaS}$ microlithons. In these high-strain zones, in the south, $\mathrm{CaF}_{2}$ folds predominantly plunge gently to the south, although $1-3 \mathrm{~km}$ to the east of the lineament, they also plunge to the north. Axial planes dip gently to steeply to the east.

Throughout the Arthur Lineament, strain levels are high for both events, although locally the intensities of $C a \mathrm{D}_{1}$ and $C a \mathrm{D}_{2}$ vary. The $C a \mathrm{~S}_{1}$ fabric is crenulated by $C a \mathrm{~S}_{2}$, while syn- $C a \mathrm{D}_{1}$ thrust faults are tight to isoclinally folded by $\mathrm{Ca} \mathrm{F}_{2}$. These conditions have also resulted in the boudinage and isoclinal folding of $\mathrm{Ca} \mathrm{D}_{1}$-related quartz segregations. In areas where $C a \mathrm{~S}_{2}$ is strongly developed, $C a \mathrm{~F}_{1}$ and $\mathrm{CaS}_{1}$ are overprinted and difficult to find.

To the east of the lineament, both $\mathrm{CaS}_{1}$ and $\mathrm{CaS}_{2}$ decrease in intensity gradually over several kilometres. In the northern and southern areas of the lineament, they are well developed (phyllitic) up to $3 \mathrm{~km}$ east of the lineament, and are weakly developed (slaty) up to $5 \mathrm{~km}$ from the eastern margin of the lineament. However, at the western boundary in the south, both foliations decrease in intensity over a much shorter distance. Within the lineament, close to its western margin, both $\mathrm{CaS} \mathrm{S}_{1}$ and $\mathrm{CaS}_{2}$ are schistose (Figure 3c). However, $300 \mathrm{~m}$ to the west of the lineament, $\mathrm{CaS}_{1}$ is no longer recognisable and $\mathrm{CaS}$ is a phyllitic fabric (Figure 3f). Two kilometres from the western boundary of the lineament, $\mathrm{CaS}$ is a smooth, continuous and parallel cleavage, which is best developed in mudstone interbeds, and is crenulated by $\mathrm{CaS}_{3}$ (Figure $3 \mathrm{~g}, \mathrm{~h}$ ).

\section{Deformation $\mathrm{CaD}_{3}$}

The $C a \mathrm{D}_{3}$ deformational event is not as strongly developed, and $C a \mathrm{~S}_{3}$ is not as pervasive as $C a \mathrm{~S}_{1}$ and $C a \mathrm{~S}_{2}$. In the study area, $C a \mathrm{D}_{3}$, which featured east-west compression, is most prominent to the west of the Arthur Lineament in the 'western' Ahrberg and Rocky Cape Groups, and in the southern parts of the 'eastern' Ahrberg Group. Minor north-south-trending post- $\mathrm{Ca} \mathrm{D}_{2}$ folds, with an associated weakly developed spaced cleavage in pelitic layers in the north of the study area, are correlated with this event.

In the south of the study area (Corinna area) the structural overprint of the $C a \mathrm{D}_{3}$ event is represented by gently south-plunging, open to close $\mathrm{Ca} \mathrm{F}_{3}$ folds, with gently dipping, 'right-way-up' western limbs, and steeply east-dipping to overturned eastern limbs. The folds are moderately inclined with west-dipping axial planes that reflect an eastdirected transport. West-dipping thrusts were mapped in the Rocky Cape Group correlates at the Longback Ridge (341360 mE, $5398900 \mathrm{mN}$ ) and at Crescent Hills (344240 mE, $5402280 \mathrm{mN}$ ). A major, west-dipping thrust is interpreted to occur in the 'western' Ahrberg Group in Guthrie Creek (339980 mE, $5390980 \mathrm{mN}$ ). This was reported by Spry (1964) as the Delville Fault, although he did not assign a specific age to the structure. We interpret these faults to be 


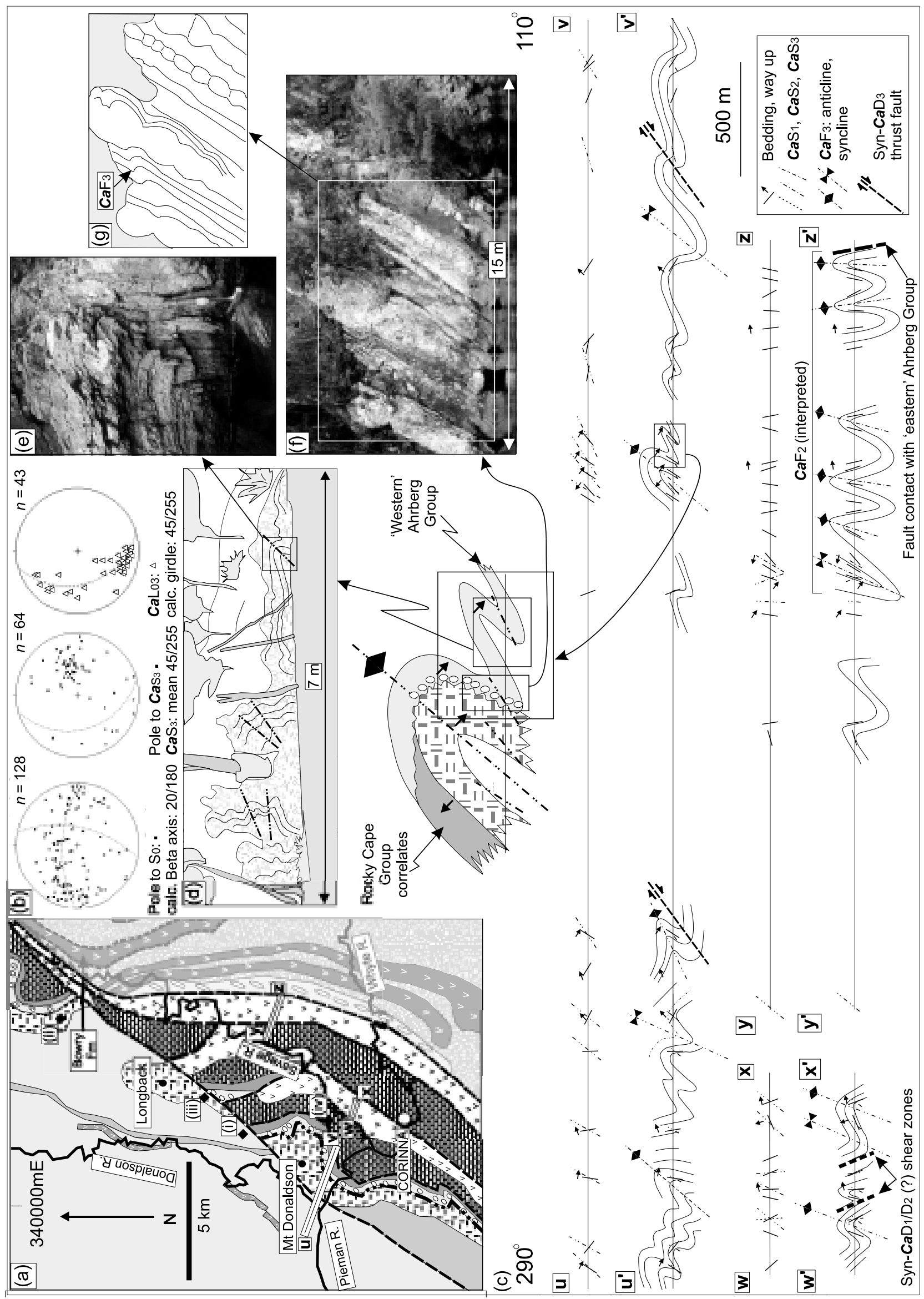


syn- $C a \mathrm{D}_{3}$ in age, based on the consistency of their style and orientation with the $\mathrm{CaS}_{3}$. Spry (1964) mapped a westdipping thrust fault on the Pieman River that intersects the Pieman River near the Donaldson River junction (the Donaldson Fault), which is associated with the main deformational event in that area, interpreted here to be $C a \mathrm{D}_{3}$. Boudinage of competent beds commonly occurs on the limbs of the $\mathrm{CaF}$ folds (Figure 4f, g: $337160 \mathrm{mE}, 539000 \mathrm{mN}$ ).

In the north of the study area (Somerset-Doctors Rocks area) $\mathrm{Ca} \mathrm{D}_{3}$ was weak. Mesoscopic symmetrical $\mathrm{CaF}$ folds have upright axial planes and shallowly dipping limbs. Associated with $C a \mathrm{~F}_{3}$ is a smooth, $2-5 \mathrm{~mm}$ spaced, parallel cleavage with discrete transitions between cleavage domains and microlithons $\left(\mathrm{CaS}_{3}\right)$ (Figure $\left.3 \mathrm{~g}, \mathrm{~h}\right)$. The age of these folds on the northwest coast is poorly constrained, and they are tentatively assigned a $C a \mathrm{D}_{3}$ age based on their relative timing post- $C a \mathrm{D}_{2}$ and pre- $D e \mathrm{D}_{1}$.

Although $C a \mathrm{D}_{3}$ is not directly dated, a Late Cambrian age was inferred based on the folding of $\mathrm{CaS}_{1}$ and $\mathrm{CaS}$, and the absence of $\mathrm{CaS}_{3}$ in the Ordovician Gordon Limestone on the west coast, north of Granville Harbour (334250 mE, $5372700 \mathrm{mN}$ ) (Figure 1).

\section{Devonian deformation}

Devonian age deformation, attributed to the Tabberabberan Orogeny, is widespread throughout western Tasmania and is interpreted to pre-date the widespread 367-332 Ma granitoid intrusion (Williams et al. 1989). In the north of the study area (Somerset - Doctors Rocks area), a mild deformational event post-dates the $C a \mathrm{D}_{3}$ event. This is tentatively correlated with the Loongana/Wilmot trend ( $\mathrm{D}_{1}$ Devonian event) of Williams et al. (1989), referred to here as $D e \mathrm{D}_{1}$. It features subhorizontal to gently plunging upright open folds $\left(D e \mathrm{~F}_{1}\right)$ that have produced a poorly developed axial-planar cleavage. The interference of the north-south-trending $\mathrm{CaF}_{3}$ and the east-west-trending $D e \mathrm{~F}_{1}$ has resulted in dome-and-basin style folding (5-15 $\mathrm{m}$ wavelength). $D e \mathrm{D}_{1}$-related faulting was not recognised in this area.

Figure 4 (a) Simplified geology of the Corinna area (map modified after Turner etal. 1991). See Figure 2 for location. (b) Stereographic projections showing effects of $\mathrm{CaF} \mathrm{F}_{3}$ deformation. (c) Cross-sections illustrating structural data (with structural interpretation for sections immediately below) for the Corinna area, west of the Arthur Lineament: $\mathrm{u}-\mathrm{v}$ is from $334100 \mathrm{mE}$, $5390700 \mathrm{mN}$ to $339050 \mathrm{mE}, 5390440 \mathrm{mN}$; w-X is from $340120 \mathrm{mE}$ $5388920 \mathrm{mN}$ to $340620 \mathrm{mE}, 5388750 \mathrm{mN}$; $\mathrm{y}-\mathrm{Z}$ is from $342590 \mathrm{mE}$, $5392170 \mathrm{mN}$ to $345240 \mathrm{mE}, 5392040 \mathrm{mN}$. (d) Detailed sketch of river section in the lowermost sandstone unit of the 'western' Ahrberg Group, illustrating the gently west-dipping long limb and steeply east-dipping to downward-facing short limb typical of the $C a \mathrm{~F}_{3}$ deformation (337280 mE, $5389940 \mathrm{mN}$ ). (e) Close-up of the hinge of a $\mathrm{CaF}_{3}$ fold in the detailed sketch area sandstone beds showing well-developed axial-planar $\mathrm{CaS}_{3}$ cleavage. (f) Downward-facing (eastern, short limb of $C a \mathrm{~F}_{3}$ ) sandstone beds in the uppermost Rocky Cape Group correlatives showing $\mathrm{CaD} \mathrm{D}_{3}$-related boudinage (337160 mE, $5390000 \mathrm{mN}$ ). (g) Sketch of (f) inset highlighting the $\mathrm{CaD}_{3}$-related boudinage. Legend for (a) is the same as in Figure 2. Area excluded from data collection ('eastern' Ahrberg Group) is shaded. (d) to ( $\mathrm{g}$ ) are mirror images of photographs/sketches (taken looking south).
In the south of the study area (Reece Dam and Corinna areas), two deformational events corresponding to the $\mathrm{D}_{4}$ of Williams etal. (1989) and known as the Zeehan/ Gormanston trend overprint the Cambrian deformation. In this paper, the first of these is referred to as $D e \mathrm{D}_{4}$, and the second is referred to as $D e \mathrm{D}_{5}$. In the south of the study area, both $D e \mathrm{D}_{4}$ and $D e \mathrm{D}_{5}$ produced gently plunging meso- to macroscopic upright open folds ( $D e \mathrm{~F}_{4}$ and $\left.D e \mathrm{~F}_{5}\right)$. The $D e S_{4}$ is a smooth, $5-10 \mathrm{~mm}$ spaced, parallel crenulation cleavage locally developed in $D e \mathrm{~F}_{4}$ fold hinges. The $D e \mathrm{~S}_{5}$ is a very weak, smooth, $<10 \mathrm{~mm}$ spaced, parallel crenulation cleavage that is also locally developed. The interference of the east-west-trending $\mathrm{DeF}_{4}$ and east-southeast-westnorthwest-trending $D e \mathrm{~F}_{5}$ has resulted in dome-and-basin style folding (10-50 $\mathrm{m}$ wavelength). Faulting interpreted to be contemporaneous with $D e \mathrm{D}_{4}$ and $D e \mathrm{D}_{5}$ is common in the southern part of the study area.

\section{DETAILED STRUCTURAL RELATIONSHIPS}

Spatial variation in intensity of all deformations $\left(\mathrm{CaD} \mathrm{D}_{1-}\right.$ $C a \mathrm{D}_{3}$ and $D e \mathrm{D}_{1}, D e \mathrm{D}_{4}$ and $D e \mathrm{D}_{5}$ ) has lead to complex overprinting relationships. The aim here is to determine how the Cambrian structural elements of the Arthur Lineament were produced. Strongly deformed Burnie Formation, on the northwest coast (Somerset - Doctors Rocks area), contains a structural transition that correlates closely with the eastern margin of the Arthur Lineament in the south and is much more exposed. The central and western portions of the Arthur Lineament are more exposed in the southern part of the study area (Reece Dam and Corinna areas). The following discussion highlights the relationships in these critical areas.

\section{Northern Arthur Lineament}

\section{STRUCTURE OF THE SOMERSET - DOCTORS ROCKS AREA}

Along the northwest coast of Tasmania in the Somerset Doctors Rocks area there is excellent exposure of the variably deformed Burnie Formation (Figure 5a). Rocks are psammites and psammopelites with minor basaltic lavas and associated intrusions (Cooee Dolerite). On the eastern flank of the Arthur Lineament, the westernmost outcrop of Burnie Formation provides evidence for the changing fold style and progressive increase in strain approaching the lineament. The deformation in this area is more complex than previously interpreted. The area is dominated by mesoscopic $C a \mathrm{~F}_{1}$ and macroscopic $C a \mathrm{~F}_{2}$ folds. Syn- $C a \mathrm{D}_{1}$ and syn- $C a \mathrm{D}_{2}$ thrusts are common (e.g. $400075 \mathrm{mE}$, $5456990 \mathrm{mN}$ and $399750 \mathrm{mE}, 5457100 \mathrm{mN}$ ). Subsequent deformation $\left(C a \mathrm{D}_{3}\right.$ and $\left.D e \mathrm{D}_{1}\right)$ has resulted in dome-andbasin style folding.

Three structural domains resulting from Cambrian-age deformation can be identified in the Somerset - Doctors Rocks area based on orientation and tightness of folds, frequency of faulting and intensity of associated fabrics: (i) eastern low-strain Domain N1 (Somerset); (ii) central low-strain Domain N2 (west of Somerset); and (iii) western high-strain Domain N3 (east of Doctors Rocks). No change in mineralogy has been detected across these three 


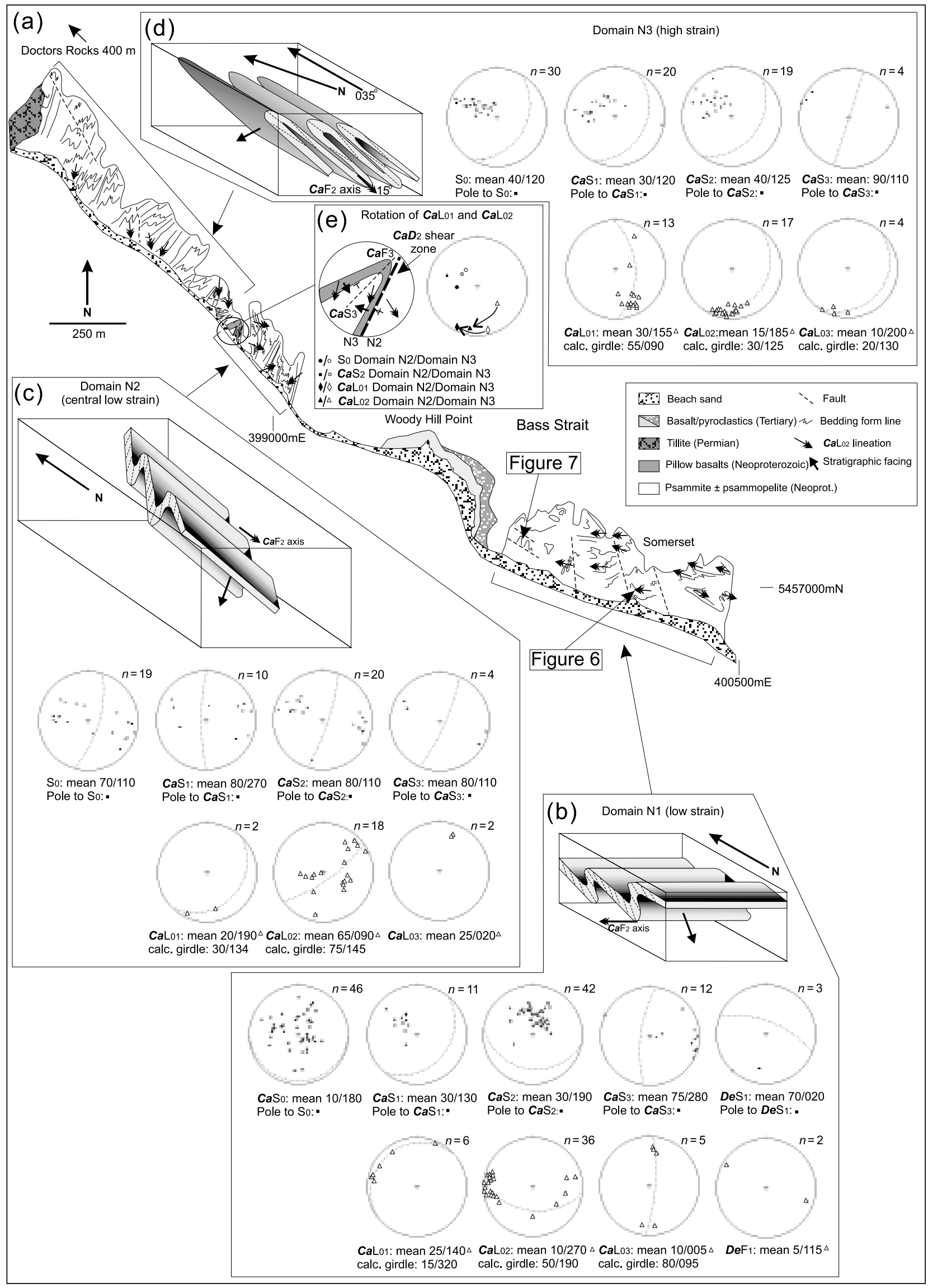


domains. While historically (Gee 1967a) the textural changes described here have been associated with increasing 'metamorphism', we found no evidence of a change of metamorphic grade across these zones.

\section{Eastern low-strain Domain N1}

Domain N1 is dominated by tight, west-plunging, southverging downward-facing parasitic $\mathrm{Ca \textrm {F } _ { 2 }}$ folds with moderately south-dipping axial planes (Figures 5b, 6a), although there is clear evidence of folding and thrusting prior to the dominant $\mathrm{Ca} \mathrm{D}_{2}$ deformation (Figure 7a-d). This pre- $\mathrm{Ca} \mathrm{D}_{2}$ event may correspond to $C a \mathrm{~F}_{1}$ and syn- $C a \mathrm{D}_{1}$ thrusting seen elsewhere in the Arthur Lineament. Several $\mathrm{Ca} \mathrm{F}_{1}$ folds are observed in the low-strain area, but these are strongly overprinted by $C a \mathrm{D}_{2}$ structures (Figures $6 \mathrm{a}, \mathrm{b}, 7 \mathrm{a}-\mathrm{d}$ ). The $\mathrm{CaS}_{1}$ axial-planar fabric is spaced $(1-3 \mathrm{~mm})$ in sandstone layers and slaty in phyllites. $C a \mathrm{~S}_{1}$ parallel boudinaged quartz segregations occur locally, in areas of more strongly developed $C a \mathrm{~S}_{1}$. Syn-CaF $\mathrm{F}_{1}$ faults (Figure $7 \mathrm{a}, \mathrm{b}$ ) are interpreted to have been thrusts and show $C a \mathrm{~F}_{1}$ folds being dragged along the fault surfaces, suggesting southwest transport. The fault planes are parallel to the $C a \mathrm{~S}_{1}$ surface and are tightly folded by $C a \mathrm{~F}_{2}$. Syn- $C a \mathrm{~F}_{2}$ faults were recognised and are also interpreted to have been thrusts (Figure 6a-c)

Throughout Domain N1 the orientation of the $\mathrm{CaD} \mathrm{D}_{2}$ related features is consistent. $C a \mathrm{D}_{2}$ is the dominant event in this domain and controls the outcrop pattern. The downward-facing $C a \mathrm{~F}_{2}$ parasitic ' $\mathrm{Z}$ ' folds have wavelengths of 5-20 $\mathrm{m}$ and have a $3 \mathrm{~mm}$ spaced to phyllitic axial-planar $\mathrm{CaS}_{2}$ cleavage that commonly represents the dominant form surface. Axial-planar fabric development varies on the different $\mathrm{Ca \textrm {F } _ { 2 }}$ fold limbs, with overturned gently dipping limbs displaying weaker cleavage development than the 'right-way-up' steep limbs. As a consequence of this foldrelated strain variation, on $C a \mathrm{~F}_{2}$ the orientation of $C a \mathrm{~L}_{02}$ changes from the overturned limb to the 'right-way-up' limb. $C a F_{2}$ are consistent in style, with moderate to steeply south-dipping 'right-way-up' short limbs, and gently southdipping overturned long limbs (Figures 5b, 6a). The consistent facing of $\mathrm{CaF}$ implies that the entire area is on one limb of a $C a \mathrm{~F}_{1}$ fold and only small-scale $C a \mathrm{~F}_{1}$ folds are present.

Figure 5 Structural overview of the Somerset - Doctors Rocks area. (a) Simplified structural map of the Somerset - Doctors Rocks area with structural domain boundaries (400405 mE, $5456925 \mathrm{mN}$ to $398310 \mathrm{mE}, 5458250 \mathrm{mN}$ ) (modified after Gee 1977). See Figure 1 for location. (b) Equal-area stereographic projections with block diagram illustrating the style and orientation of the dominant folding $\left(\mathrm{CaF}_{2}\right)$ for Domain N1 (downward-facing parasitic $\mathrm{CaF}_{2}$ fold) (modified after Gee 1977). (c) Equal-area stereographic projections with block diagram illustrating the style and orientation of the dominant folding $\left(\mathrm{CaF}_{2}\right)$ for Domain $\mathrm{N} 2$ (steepening of $\mathrm{CaF_{2 }}$ due to type 2 refolding by $\mathrm{CaF}$ ). (d) Equalarea stereographic projections with block diagram illustrating the style and orientation of the dominant folding $\left(\mathrm{CaF} \mathrm{F}_{2}\right)$ for Domain N3 (rotation of $\mathrm{CaF}_{2}$ due to simple shear with component of oblique shortening). (e) Detailed sketch and equal-area stereographic projection illustrating the change in orientation of the dominant lineation $\left(\mathrm{CaL}_{02}\right)$ at the boundary between Domains N2 and N3.
Overprinting the $C a \mathrm{D}_{1}$ and $C a \mathrm{D}_{2}$ structures in the both the low- and high-strain domains are folding events correlated with $C a \mathrm{D}_{3}$ to the west and south, and $D e \mathrm{D}_{1}$ (Loongana/Wilmot trend) to the east. The $C a \mathrm{D}_{3}$ event has open upright $\mathrm{Ca} \mathrm{F}_{3}$ folds and a weakly developed spaced axial-planar cleavage $\left(\mathrm{CaS}_{3}\right)$, only observed in the minor mudstone interbeds (Figures 6b, c, 7a). This generation has been folded by open east-west-trending $D e \mathrm{~F}_{1}$ that has a poorly developed, spaced axial-planar cleavage, which is only recognised in some pelitic layers, resulting in domeand-basin interference patterns.
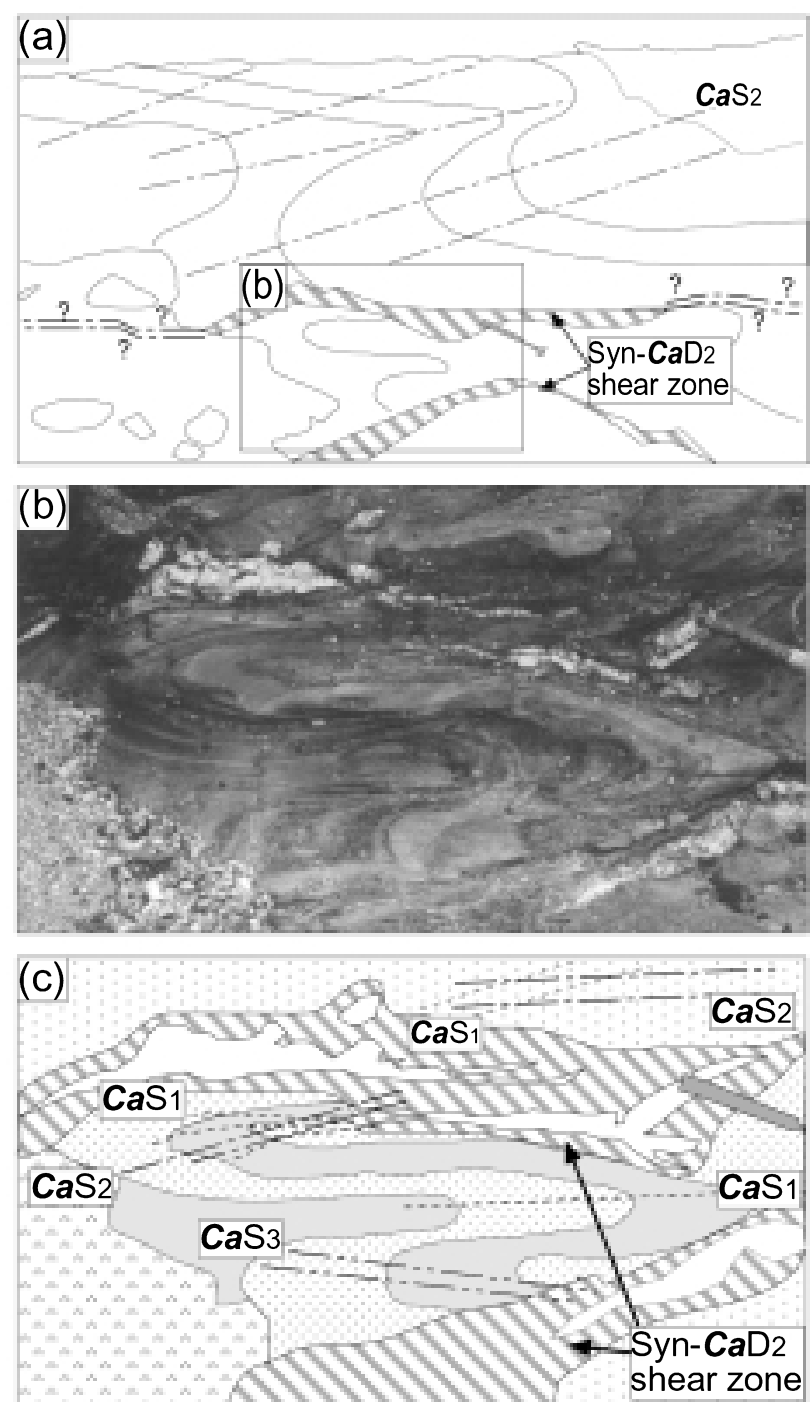

Figure 6 Cambrian deformation in Domain N1 at Somerset (400075 mE, $5456990 \mathrm{mN}$ ). See Figure 5 for location. (a) Sketch of downward-facing, south-verging $\mathrm{CaF}_{2}$ parasitic $\mathrm{S}$ fold in the Cambrian age low-strain domain $\mathrm{N} 1$, with a Cambrian age $C a \mathrm{~F}_{1}$ fold [small-scale fold enlarged in (b)] overprinted by $\mathrm{CaS}_{2}$ evident in the bottom of the sketch. $\mathrm{CaS}_{2}$ cleavage is the dominant form surface. The syn- $C a \mathrm{D}_{1}$ and syn- $C a \mathrm{D}_{2}$ thrusting typically occurs close to boundaries between psammitic and psammopelitic sequences. (b) $C a \mathrm{~F}_{1}$ fold on lower surface of syn- $C a \mathrm{D}_{2}$ shear and $\mathrm{CaS} \mathrm{S}_{2}$ transecting the $\mathrm{Ca \textrm {F } _ { 1 }}$ fold. (c) Sketch of syn- $\mathrm{Ca \textrm {D } _ { 2 }}$ thrust and $\mathrm{CaS}_{2}$ overprinting $\mathrm{Ca \textrm {F } _ { 1 }}$ fold. 


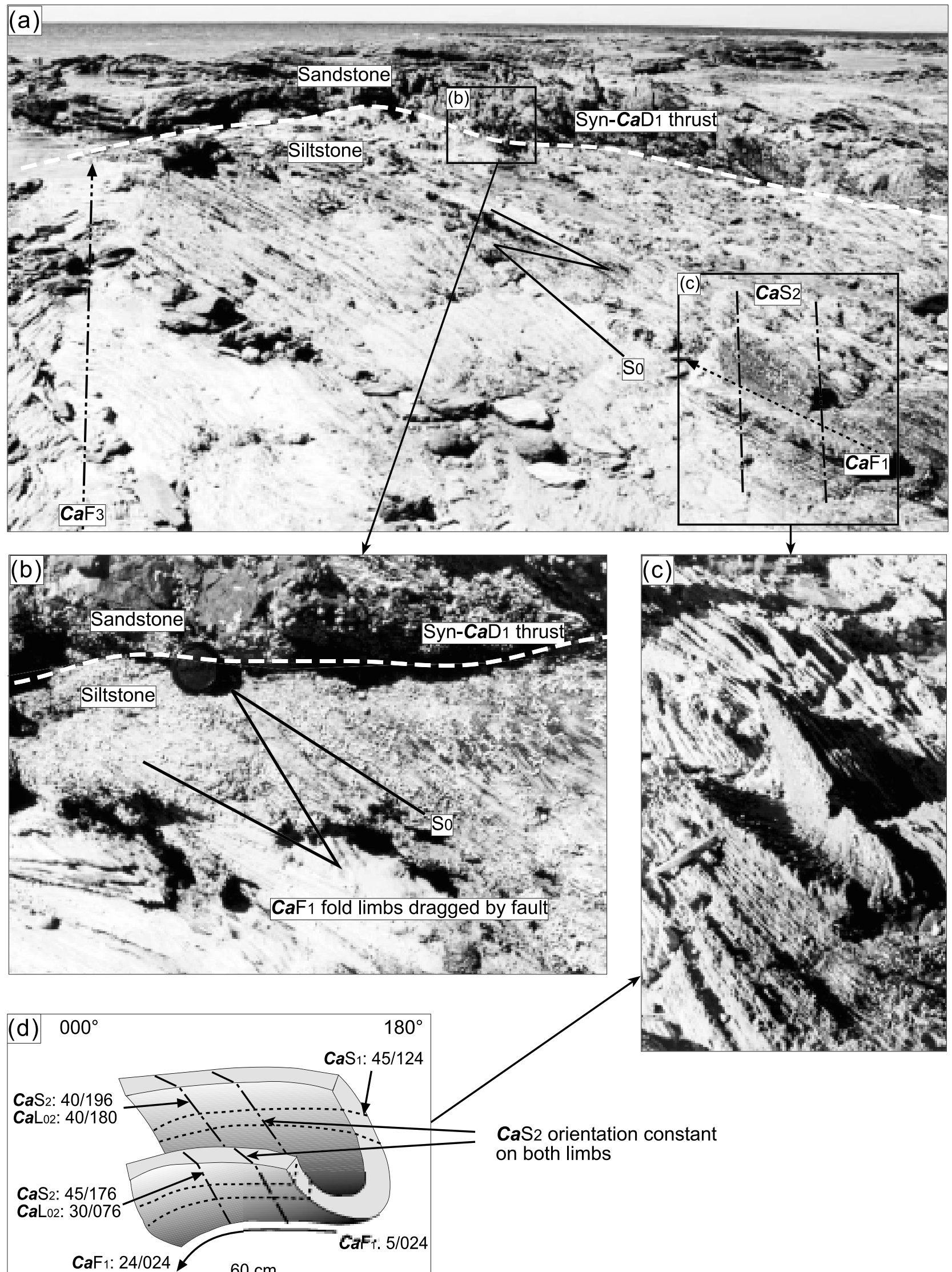


Central low-strain Domain N2 (west of Somerset)

At outcrop-scale, this domain is dominated by $C a \mathrm{D}_{2}$ structures, although their orientations are different to those in Domain N1. The syn- $\mathrm{Ca} \mathrm{D}_{2}$ strain level is similar to Domain $\mathrm{N} 1$, as is the $C a \mathrm{~F}_{2}$ vergence. The area is dominated by overturned, moderately east-dipping $\mathrm{S}_{0}$ and downward-facing $C a \mathrm{~F}_{2}$ parasitic ' $\mathrm{Z}$ ' folds. Syn- $C a \mathrm{D}_{1}$ fault zones truncate $\mathrm{S}_{0}$. $C a \mathrm{~L}_{01}\left(\mathrm{~S}_{0} / C a \mathrm{~S}_{1}\right.$ intersection lineation) and $C a \mathrm{~L}_{02}\left(\mathrm{~S}_{0} / C a \mathrm{~S}_{2}\right.$ intersection lineation) lineations have moderate plunges trending to the northeast and southwest (Figure $5 \mathrm{c}$ ). $\mathrm{Ca \textrm {F } _ { 3 }}$ are gentle folds in $\mathrm{S}_{0}$ and the earlier cleavages, and $\mathrm{CaS}$ is a steeply west-dipping weak, spaced cleavage. $D e \mathrm{D}_{1}$ is weak in this domain.

\section{Western high-strain Domain N3 (east of Doctors Rocks)}

Rocks in Domain N3 are more varied than in Domains N1 and N2, featuring psammopelitic schist, and chlorite zone metabasalt interbedded with minor volcanogenic metasediments. The metabasalt is interpreted to be the extrusive equivalent of the Cooee Dolerite, which is intruded into the Burnie Formation $6.5 \mathrm{~km}$ to the east (Spry 1957b; Gee 1967b).

This domain is structurally more complex than the lower strain domains to the east. $C a \mathrm{~F}_{1}$ and syn- $C a \mathrm{D}_{1}$ thrusts are more prevalent, as are $C a \mathrm{~F}_{2}$ folds. $C a \mathrm{~F}_{1}$ folds in Domain N3 are metre-wavelength isoclinal folds and display extreme thinning of sandstone layers on the limbs. $C a \mathrm{~S}_{1}$ and $\mathrm{Ca} \mathrm{S}_{2}$ are finely spaced $(1 \mathrm{~mm})$ and phyllitic to schistose (Figure 3e). Locally, boudinaged quartz segregations are found parallel to $\mathrm{CaS}_{1}$. In contrast to Domains N1 and $\mathrm{N} 2$, here $C a \mathrm{~F}_{1}$ and $C a \mathrm{~F}_{2}$ plunge to the south-southeast, with axial planes dipping gently to moderately to the east-southeast (Figure $5 \mathrm{~d}$ ). Outcrop-scale $C a \mathrm{~F}_{3}$ and $D e \mathrm{~F}_{1}$ are minor.

\section{Southern Arthur Lineament}

\section{STRUCTURE OF THE REECE DAM AND SPILLWAY AREA}

Reece Dam (344900 mE, $5379020 \mathrm{mN}$ ) and spillway (345120 mE, $5378860 \mathrm{mN}$ ) are situated on the lower Pieman River, $2.5 \mathrm{~km}$ to the west of the eastern margin of the Arthur Lineament (Figure 8a). The engineering and excavation works below the dam and spillway along the Pieman River and Stringer Creek provide excellent exposure of the contact between the high-strain Oonah Formation and a similarly deformed metasedimentary unit that is structurally interlayered with a tholeiitic metagabbroic unit (Turner 1992; Crawford 1992; Turner \& Crawford 1993). To the west of this metasedimentary unit, and also exposed, is the faulted contact with the Bowry Formation. Turner

Figure 7 Western end of Domain N1 (399750 mE, $5457100 \mathrm{mN}$ ) showing syn- $C a \mathrm{D}_{1}$ thrust and $C a \mathrm{~F}_{1}$, folded by $C a \mathrm{~F}_{2}$ and overprinted by $\mathrm{CaS}_{2}$. See Figure 5 for location. The syn- $\mathrm{Ca \textrm {D } _ { 1 }}$ and $C a \mathrm{D}_{2}$ features are overprinted by $C a \mathrm{D}_{3}$. (a) Overview of detailed study area. (b) Close-up of thrust contact that features $\mathrm{Ca} \mathrm{F}_{1}$ folds being dragged along the fault, suggesting southwest transport (lens cap $50 \mathrm{~mm}$ diameter). (c) Example of $\mathrm{Ca} \mathrm{F}_{1}$ fold, with timing relationship to $\mathrm{Ca \textrm {F } _ { 2 }}$ illustrated by transecting $\mathrm{Ca \textrm {S } _ { 2 }}$ cleavage. (d) Sketch of $\mathrm{CaF_{1 }}$ fold illustrating the overprinting by transecting $\mathrm{CaS}_{2}$, which is consistent on both limbs. and Crawford (1993) interpreted the metagabbro to intrude the Oonah Formation, although Crawford (1992) noted its chemical similarity to some of the amphibolites in the Bowry Formation. We interpret the metagabbro to occur in a fault-bounded block of metasediments that lies between the Oonah Formation and the Bowry Formation. The metasedimentary unit is lithologically similar to units of the 'eastern' Ahrberg Group, and it has undergone a similar level of deformation, although in its current position it is separated from the 'eastern' Ahrberg Group by the Bowry Formation. The geology becomes more complex west of the spillway, towards the boundary of the Bowry Formation, in the vicinity of lower Stringer Creek and the Reece Dam power station (Figure 9). Mafic schist and amphibolite bodies become common, and syn- $C a \mathrm{D}_{1}$ and syn- $\mathrm{Ca} \mathrm{D}_{2}$ faults are more frequent. Furthermore, structural repetition and the interlayering of units of different metamorphic grade were observed.

The area is dominated by $C a \mathrm{~S}_{1}, C a \mathrm{~S}_{2}$, syn- $C a \mathrm{D}_{1}$ and syn- $C a \mathrm{D}_{2}$ faults, and based on consistent $C a \mathrm{~F}_{2}$ vergence is positioned on the downward-facing, east-dipping limb of a $C a \mathrm{~F}_{2}$ fold. The orientations of $\mathrm{S}_{0}, C a \mathrm{~S}_{1}$ and $C a \mathrm{~S}_{2}$ are variable due to refolding by $C a \mathrm{~F}_{3}, D e \mathrm{~F}_{4}$ and $D e \mathrm{~F}_{5}$. Late faults, possibly Devonian in age, also cut the early structures. The varying orientation, style and intensity of the $C a \mathrm{D}_{1}$ and $C a \mathrm{D}_{2}$ structures enable the area to be divided into two structural domains (Domains S1 and S2) (Figure 8b).

\section{Eastern spillway: Domain S1}

Domain $\mathrm{S} 1$ is defined as the short limb and hinge-zone of a late $\left(C a \mathrm{D}_{3}\right.$ or $\left.D e \mathrm{D}_{5}\right)$ upright southeast-plunging ' $\mathrm{Z}$ ' fold with a wavelength of $150 \mathrm{~m}$. The domain features pervasive development of $C a \mathrm{~S}_{1}$ and $C a \mathrm{~S}_{2}$, which have consistent vergence relationships with $\mathrm{S}_{0} . C a \mathrm{~F}_{2}$ are small-scale (5-15 cm wavelength) folds that verge to the southeast. The folds feature moderately southeast-dipping overturned long limbs, steeply southeast-dipping upright short limbs. $\mathrm{CaS}_{2}$ is finely spaced (1-2 mm) and phyllitic to schistose. The $C a \mathrm{~F}_{2}$ folds refold the very finely spaced $(1 \mathrm{~mm})$ phyllitic to schistose $\mathrm{Ca \textrm {S } _ { 1 }}$ cleavage.

$\mathrm{CaS}_{1}$ - and $\mathrm{CaS}_{2}$-parallel faulting and shearing is common. The metagabbro described by Crawford (1992) and Turner and Crawford (1993) outcrops in Domain S1 as boudins that have intense cleavage developed around their margins due to competency contrast between the metagabbro and the surrounding quartz-mica-albitecarbonate schist. In contrast, the cores of the boudins are unfoliated.

$\mathrm{DeF}_{4}$ folds are minor, weakly developed, small-scale ( $1 \mathrm{~m}$ wavelength) folds and rarely produce an axial-planar fabric. Open $D e \mathrm{~F}_{5}$ folds overprint $D e \mathrm{~F}_{4}$ and produce domeand-basin interference patterns. $D e S_{5}$ is a subvertical spaced cleavage.

\section{Western spillway: Domain S2}

Domain S2 is the moderately dipping long limb of the late $\left(C a \mathrm{D}_{3}\right.$ or $\left.\mathrm{De} \mathrm{D}_{5}\right)$ upright southeast-plunging fold (Figure $8 \mathrm{~b}$ ). $C a \mathrm{~S}_{1}$ and $C a \mathrm{~S}_{2}$ are pervasively developed. $\mathrm{CaS}$ is a finely spaced schistosity $(0.5 \mathrm{~mm})$ and produces a $C a \mathrm{~L}_{01}$ intersection lineation. $\mathrm{CaS}_{2}$ is also schistose (1-2 mm spacing) and produces a $C a \mathrm{~L}_{02}$ intersection lineation. 


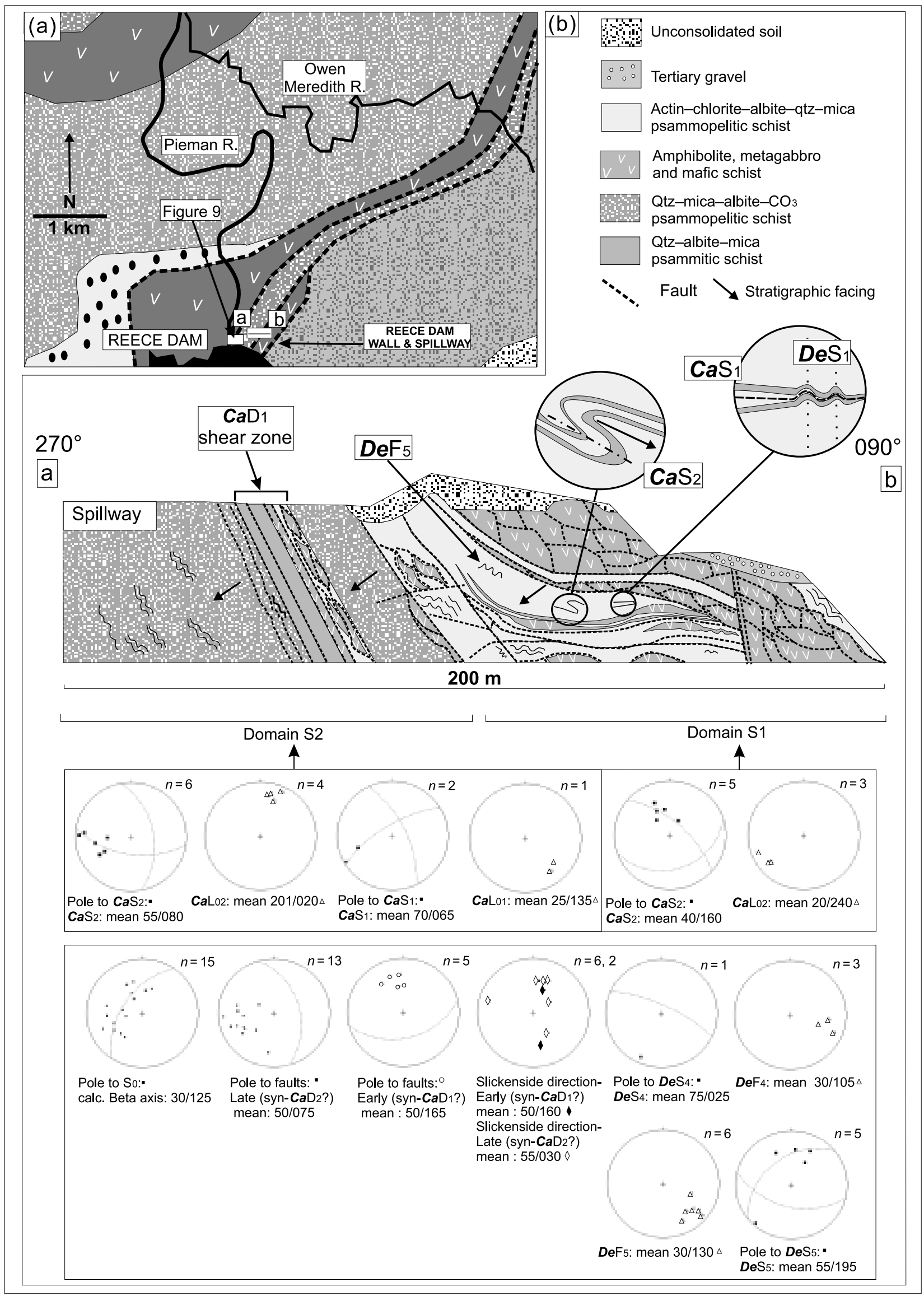


In this domain $D e F_{4}$ folds are not evident. $D e S_{5}$ is a locally developed spaced $(5-10 \mathrm{~mm})$ cleavage. There are minor examples of $\mathrm{DeS}_{5}$-parallel extensional quartz veins, which occur in the hinge zones of the $D e \mathrm{~F}_{5}$ folds. The syn- $C a \mathrm{D}_{1}$ and syn- $C a \mathrm{D}_{2}$ faults display a consistent reverse sense of movement and predominantly dip to the east (Figure 8b). They lack fault gouge or breccia.

As on the north coast in the Somerset - Doctors Rocks area, in the southern study area, $0-7 \mathrm{~km}$ to the east of the Arthur Lineament, $\mathrm{CaS} \mathrm{S}_{1}$ and $\mathrm{CaS} \mathrm{S}_{2}$ cleavages are evident and become increasingly well developed closer to the lineament. Although $\mathrm{CaF} 2$ folding is evident in this zone, it has not reached its maximum intensity. Between $0 \mathrm{~km}$ and $3 \mathrm{~km}$ to the west of the eastern boundary of the Arthur Lineament (i.e. inside the lineament), the structural style is dominated by $C a \mathrm{~F}_{1}$ and $C a \mathrm{~F}_{2}$ folding. In this zone, syn- $C a \mathrm{D}_{1}$ and $C a \mathrm{D}_{2}$ faulting are infrequent, and do not cause major disruption to the stratigraphic sequence. However, the structural style at Reece Dam and spillway and proximal to the Bowry Formation to the west, is markedly different, with faulting associated with $C a \mathrm{D}_{1}$ and $C a \mathrm{D}_{2}$ becoming dominant. The increase in the frequency of early faulting (syn- $C a \mathrm{D}_{1}$

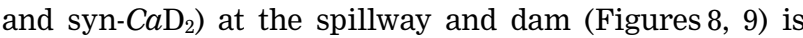
representative of the style of deformation within the most strongly deformed parts of the Arthur Lineament. Individual syn- $C a \mathrm{D}_{1}$ - and syn- $C a \mathrm{D}_{2}$-related fault-bounded slices are typically $5-10 \mathrm{~m}$ thick, with strongly foliated to sheared margins demonstrating well developed S-C fabrics. The boundary zone on the east of the Bowry Formation is dominated by small-scale faults (Figure 9). The faults have stacked slices of different composition and different metamorphic grade, including graphitic phyllite, pelitic and psammopelitic schist, chlorite and mafic schist, amphibolite and minor quartz-feldspar schist (344900 mE, $5379075 \mathrm{mN}$ ). The complex fault relationships are critical to the understanding of this strongly deformed zone of the Arthur Lineament. These contrasting styles of deformation, fault-dominated versus fold-dominated, occur on a mesoscale (Figure 8) and on a regional scale. On a regional scale, this is interpreted to have produced stacks of regionally mappable fault-bounded slices of contrasting metamorphic grades, such as the allochthonous Bowry Formation.

\section{STRUCTURE OF THE CORINNA AREA}

$C a \mathrm{D}_{3}$, featuring asymmetric south-plunging $\mathrm{CaF} 3$, dominates the Corinna area to the west of the Arthur Lineament in the Rocky Cape Group correlates and the 'western' Ahrberg Group (Figure $4 \mathrm{a}, \mathrm{b}$ ). $C a \mathrm{~F}_{1}$ are not observed, and small-scale $\mathrm{CaF_{2 }}$ are uncommon. However, foliations associated with $C a \mathrm{D}_{1}$ and $C a \mathrm{D}_{2}$ were found in some pelitic layers. In the Rocky Cape Group correlates, key examples of the overprinting relationships between $\mathrm{CaS}_{1}, \mathrm{CaS}_{2}$ and $\mathrm{CaS}$ are seen at: (i) Sabbath Creek (339200 mE, $5394155 \mathrm{mN})$; (ii)

Figure 8 Reece Dam and spillway. See Figure 2 for location. (a) Location map (modified after Turner et al. 1991) with section line A-B. (b) Cross-section of the Reece Dam - spillway area (section A-B) with equal-area stereographic projections for Domains S1 and $\mathrm{S} 2(3345300 \mathrm{mE}, 5378875 \mathrm{mN}$ to $345100 \mathrm{mE}, 5378875 \mathrm{mN})$ Legend for (a) is the same as in Figure 2.
Crescent Hills (343860 mE, $5401800 \mathrm{mN}$ ); and (iii) on the Longback Ridge (340600 mE, $5395280 \mathrm{mN}$ ). Less wellpreserved examples are seen in the 'western' Ahrberg Group at (iv) Elizabeth Ridge (340530 mE, $5388750 \mathrm{mN}$ ) (Figure 4a). CaS $\mathrm{S}_{1}$ is identifiable in the Rocky Cape Group correlates and the 'western' Ahrberg Group as a weakly developed $\mathrm{S}_{0}$-parallel foliation, defined by muscovite, whereas $\mathrm{CaS}_{2}$ is a weakly developed differentiated crenulation cleavage that cuts $\mathrm{S}_{0}$ at a high angle. The westdipping $\mathrm{CaS}_{3}$ is a spaced (3-5 mm) cleavage; it crenulates $C a \mathrm{~S}_{2}$ and also cuts $\mathrm{S}_{0}$ at a high angle (Figure $3 \mathrm{~g}, \mathrm{~h}$ ). $C a \mathrm{~F}_{3}$ have west-dipping axial planes, with steeply east-dipping to overturned eastern limbs and gently west-dipping, 'right-way-up' western limbs (Figure 4c-e). Quartzite on the overturned eastern limbs is strongly boudinaged (Figure 4f, g).

\section{DISCUSSION}

Despite a distance of $60 \mathrm{~km}$ separating the outcrop studied in the north (Somerset - Doctors Rocks area) and south (Reece Dam and Corinna areas) of the Arthur Lineament, there is strong evidence supporting the correlation of deformational events between these areas. Evidence for the Cambrian age deformations $\left(C a \mathrm{D}_{1}-C a \mathrm{D}_{3}\right)$ being widespread regional events is supported by mapping in the southern Arthur Lineament, where the fabric associated with these deformations have been mapped over a $40 \times 10 \mathrm{~km}$ area. The $C a \mathrm{D}_{1}$ and $C a \mathrm{D}_{2}$ events in the Somerset - Doctors Rocks area are correlated with those in the south of the Arthur Lineament (Reece Dam and surrounding area), based on the consistent style of $C a \mathrm{D}_{1}$ and $C a \mathrm{D}_{2}$ features, orientations, and the interference relationships. In both areas the $\mathrm{CaS} \mathrm{S}_{1}$ and $\mathrm{CaS}$ foliations increase in intensity from a spaced cleavage to a schistosity approaching the lineament from the east. Widespread interference between the strongly developed high-strain $C a \mathrm{D}_{1}$ and $C a \mathrm{D}_{2}$ events, followed by overprinting of the less intense third Cambrian deformation $\left(\mathrm{Ca \textrm {D } _ { 3 }}\right)$ and subsequent multiple Devonian age deformations $\left(D e \mathrm{D}_{1}\right.$, $D e \mathrm{D}_{4}, D e \mathrm{D}_{5}$ ) has resulted in complex, outcrop patterns. The orientations of the dominant, early structures are regionally consistent, but show evidence of local refolding.

In both the northern and southern areas of the Arthur Lineament, $C a \mathrm{D}_{1}$ and $C a \mathrm{D}_{2}$ structures change orientation from east to west. The $C a \mathrm{D}_{1}$ event is interpreted to be a major deformational event, but overprinting by the intensely developed $C a \mathrm{D}_{2}$ event obscures many of the $\mathrm{Ca} \mathrm{D}_{1}$ structures. On the north coast within Domains $\mathrm{N} 1$ and $\mathrm{N} 2$, recognisable $C a \mathrm{D}_{1}$ structures are rare. Throughout Domains N1 to N3 the orientation of the $C a \mathrm{D}_{1}$ structures is dependent on the intensity of $C a \mathrm{D}_{2}$ and the $C a \mathrm{~F}_{2}$ fold position. Several $C a \mathrm{D}_{1}$ thrust faults, folded by $C a \mathrm{~F}_{2}$ and transected by $C a \mathrm{~S}_{2}$, are present along the attenuated $C a \mathrm{~F}_{1}$ limbs.

The most significant change in orientation of $C a \mathrm{~L}_{01}$ and $C a \mathrm{~L}_{02}$ occurs at the boundary between Domains N2 (low strain) and N3 (high strain) (Figure 5e) (398780 mE, $5457890 \mathrm{mN}$ ). This location also corresponds with a major early shear zone, interpreted to be Cambrian in age $\left(C a \mathrm{D}_{2}\right)$. In Domain N2, on the overturned $C a \mathrm{~F}_{2}$ limbs, $C a \mathrm{~L}_{01}$ and 


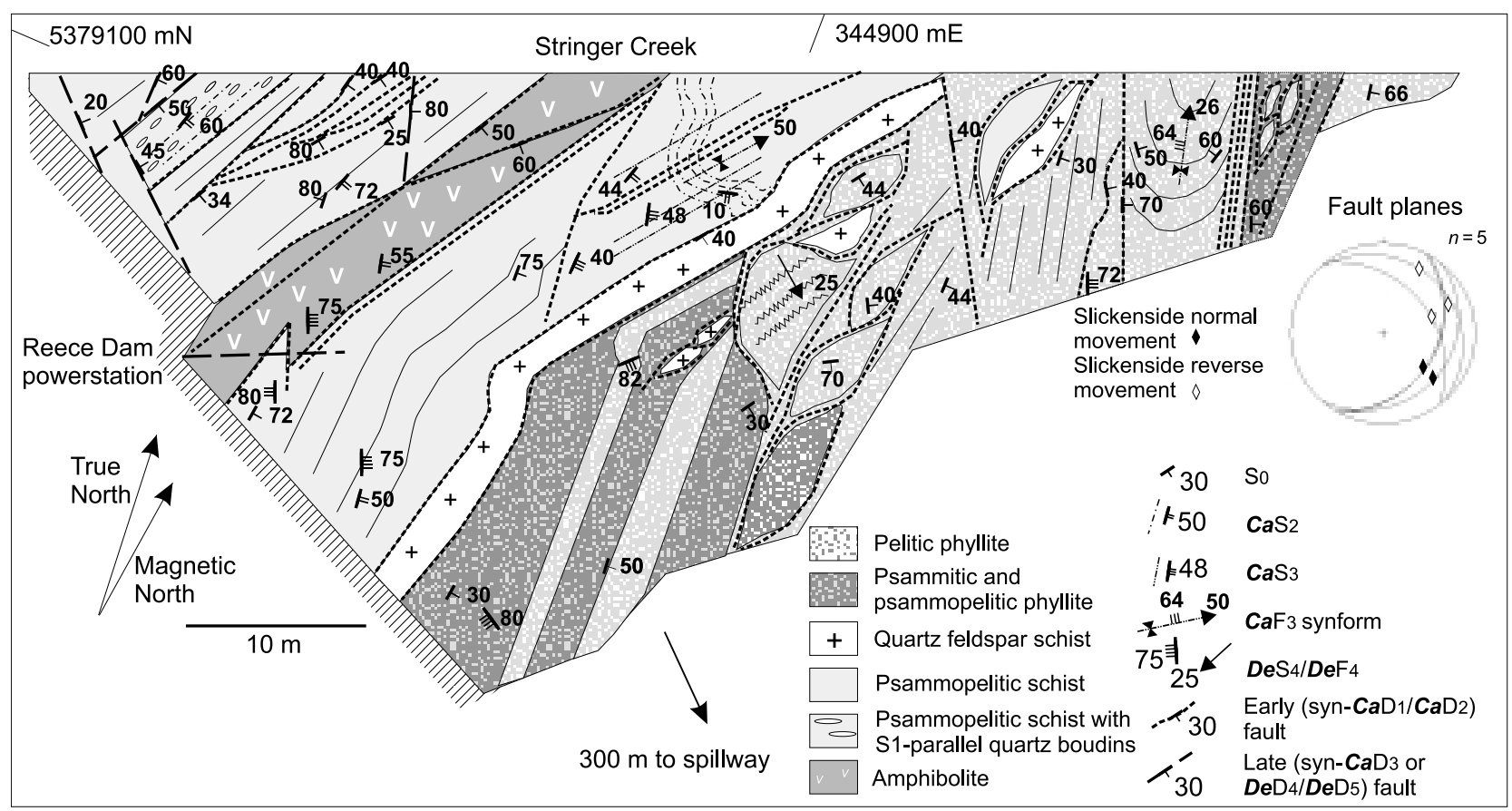

Figure 9 Detailed geological map from Stringer Creek near Reece Dam power station ( $344900 \mathrm{mE}$, $5379100 \mathrm{mN})$. See Figure 8 for location. The intense faulting has resulted in the stacking of slices of differing composition and metamorphic grade. Measured fault planes with movement indicators are shown in the stereographic projection.

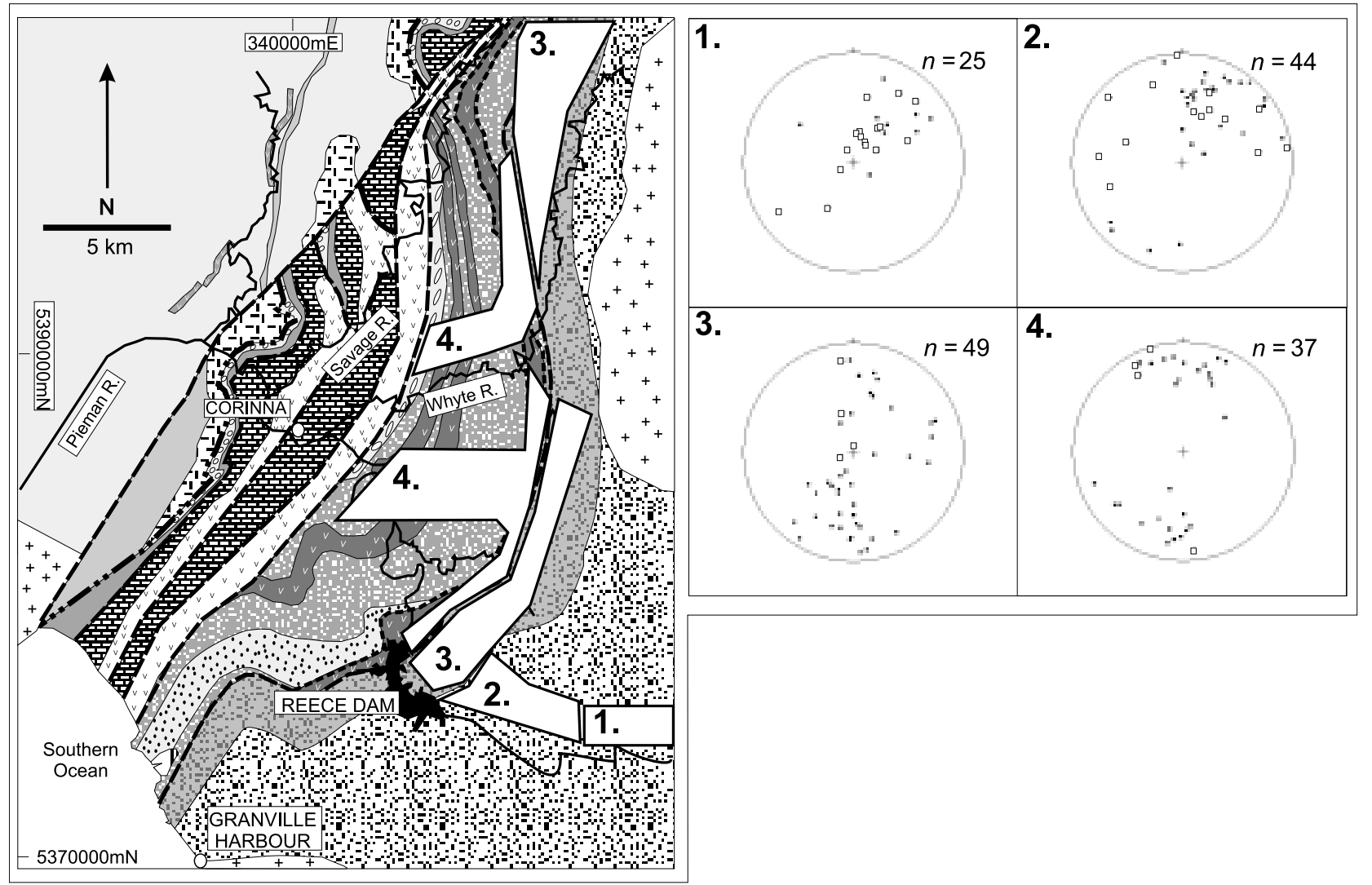

Figure 10 Simplified geological map of the southern Arthur Lineament showing generalised structural data collection areas (map modified after Turner et al. 1991). Accompanying the defined areas 1-4 are stereographic projections of $C a \mathrm{~L}_{02}$ lineations, which show the change in orientation across the low strain - high strain boundary on the edge of the Arthur Lineament. Note the change in orientation from 1 [moderately plunging to the northeast ( $>3 \mathrm{~km}$ to the east of the lineament)] to 2 [predominantly gently to moderately plunging to the north-northeast (0-3 km to the east of the lineament)] to 3 [predominantly plunging moderately to the north and south ( $0-3 \mathrm{~km}$ to the west of the lineament's eastern boundary)] to 4 [plunging gently to the north and south (from the core of the lineament to its western boundary)]. Legend for map is the same as in Figure 2. $\square, C a \mathrm{~L}_{01} ; \mathbf{\square}, C a \mathrm{~L}_{02}$. 
$C a \mathrm{~L}_{02}$ plunge to the east-southeast. Close to the shear zone, the orientation of $C a \mathrm{~L}_{01}$ and $C a \mathrm{~L}_{02}$ rotates. On the predominantly high-strain western side of the shear zone (Domain N3), the lineations plunge towards the south-southwest.

In the Savage River to Reece Dam region (southern study area), outside the Arthur Lineament and close to its eastern margin (including parts of the high-strain Oonah Formation), areas with steeply plunging $C a \mathrm{~L}_{01}$ and $\mathrm{Ca} \mathrm{L}_{02}$ are present (areas 1-3 in Figure 10). However, within the lineament, in the high-strain Oonah Formation and the 'eastern' Ahrberg Group, $C a \mathrm{~L}_{01}$ and $C a \mathrm{~L}_{02}$ have consistent shallow plunges to the south, and in minor cases plunge shallowly to the north (areas 3 and 4 in Figure 10).

Further to this, outcrop on the west coast, between Granville Harbour and Ahrberg Bay, shows a similar change in structural style and $C a \mathrm{~L}_{01}$ and $C a \mathrm{~L}_{02}$ lineation direction to the Savage River - Reece Dam area. The coastal exposure of the Arthur Lineament in this area is divided into 'northern' and 'southern' areas, separated by the weakly deformed Ordovician to Silurian Duck Creek sequence (Figures 11, 12). The two areas have distinctive differences in structural style, reflecting different strain intensities. The 'southern' area exposes the low strain to high strain transition zone of the eastern boundary of the Arthur Lineament, with deformed Oonah Formation and 'eastern' Ahrberg Group correlates outcropping (Figure 11). The strain level in this area is intense, producing phyllitic to schistose $C a S_{1}$ and $C a S_{2}$ foliations, although it is less intense than in the core of the Arthur Lineament, which crops out further to the north along the coastline (Figure 12). This less strongly deformed area is dominated by $C a \mathrm{~F}_{1}$ and $C a \mathrm{~F}_{2}$ folding, with faulting relatively infrequent, although early faults become increasingly common in the northern part of this section (Figure $11 \mathrm{a}-\mathrm{c}$ ). $C a \mathrm{~L}_{01}$ and $C a \mathrm{~L}_{02}$ lineations plunge gently to moderately to the northwest and southeast (Figure 11d).

In contrast, the 'northern' area exposes the core of the Arthur Lineament, with strain levels at their most intense within the lineament (Figure 12). $\mathrm{CaS}$ and $\mathrm{CaS}_{2}$ are schistose, and while $C a \mathrm{~F}_{1}$ and $C a \mathrm{~F}_{2}$ folding is common, syn- $C a \mathrm{D}_{1}$ and $C a \mathrm{D}_{2}$ thrust faults causing repetition of units are much more frequent than in the 'southern' area (Figure 12a-c). In the 'northern' area, the $C a \mathrm{~L}_{01}$ and $C a \mathrm{~L}_{02}$ lineations on average plunge moderately to the south (Figure 12d). The increase in faulting and strain from the southern area to the northern area is accompanied by a change in orien-

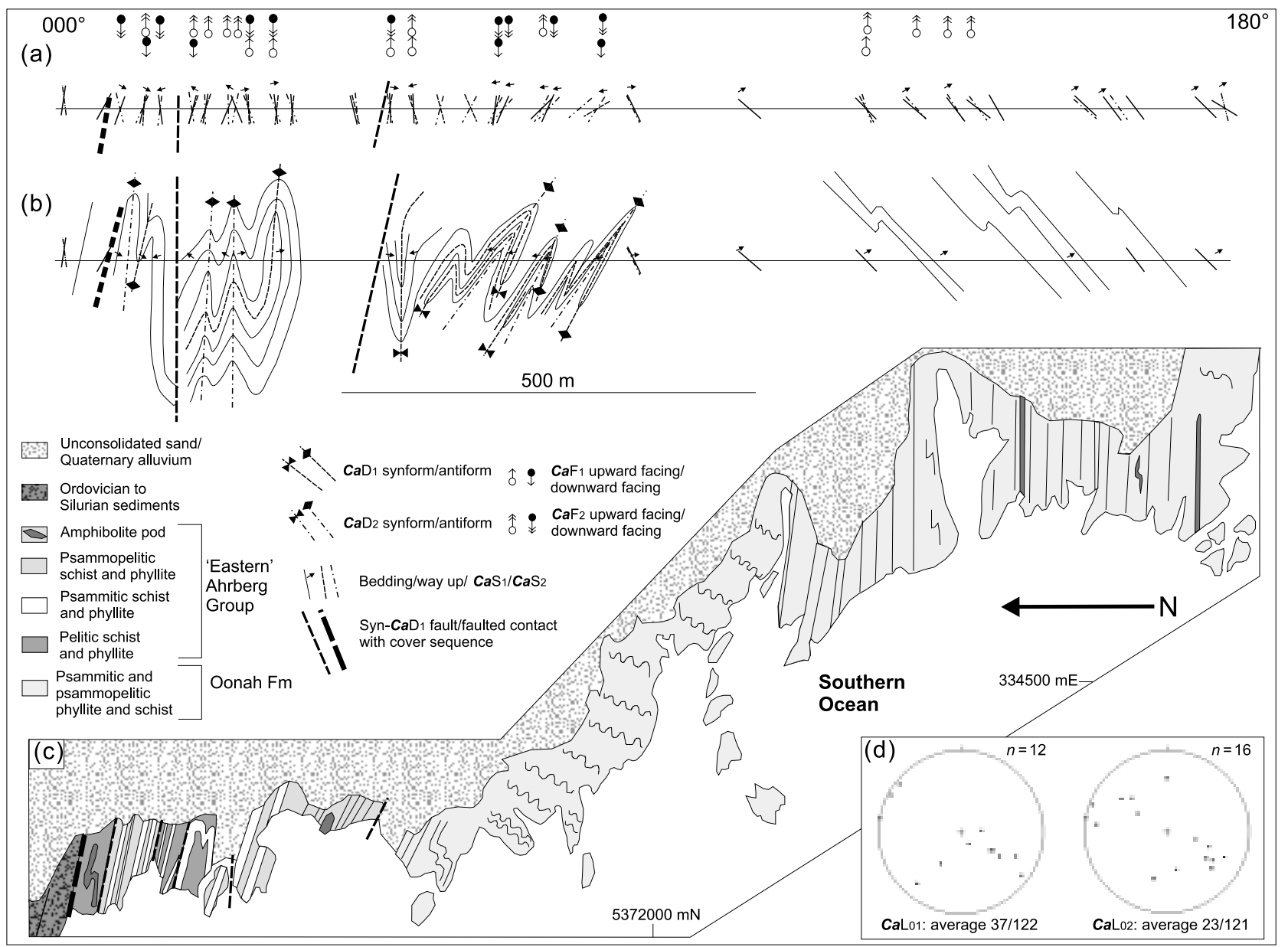

Figure 11 Structural style of the southernmost edge of the Arthur Lineament on the west coast of Tasmania, north of Granville Harbour ( $3349915 \mathrm{mE}, 5371325 \mathrm{mN}$ to $334300 \mathrm{mE}, 5372610 \mathrm{mN}$ ). See Figure 2 for location. (a) Cross-section illustrating structural data for the west coast exposure of the southern Arthur Lineament. (b) Interpretive cross-section for the area. (c) Simplified geological map of the section. (d) Stereographic projections for $C a \mathrm{~L}_{01}$ and $C a \mathrm{~L}_{02}$ illustrating the predominantly shallow to moderate southeast plunge. 
tation of $C a \mathrm{~F}_{1}$ and $C a \mathrm{~F}_{2}$ into alignment with the stretching direction.

The Devonian deformation has caused some refolding in the 'northern' area, resulting in a change in trend of the $\mathrm{CaS}_{1}$ and $\mathrm{CaS}$ foliations to west-southwest. The shallow, east-southeast-plunging axis of this later event is interpreted to have resulted in some steepening of the $C a \mathrm{~L}_{01}$ and $C a \mathrm{~L}_{02}$ lineations, although the overall effect of this event is minor.

The uniform change in orientation of $C a \mathrm{~L}_{01}$ and $C a \mathrm{~L}_{02}$ from the low-strain domain to the high-strain domain, in the Somerset - Doctors Rocks area and over the length of the southern study area $(45 \mathrm{~km})$ (Figures 10-12), is considered to be a result of syn- $C a \mathrm{D}_{2}$ rotation due to increasing strain. Based on similarities with examples of shear-related rotation discussed by Ridley and Casey (1989) and Dewey et al. (1998), it is suggested that the change in orientation associated with $C a \mathrm{D}_{2}$ described above is the result of a strongly rotational shear component with a north-south stretching direction in the high-strain zone at the core of the Arthur Lineament.

The east-west trend of the $C a \mathrm{~F}_{2}$ hinges and fold vergence in Domain N1 can be interpreted to reflect southdirected transport, provided the overturning occurred during $C a \mathrm{D}_{2}$. The alternative possibility is that the $C a \mathrm{~F}_{2}$ are downward-facing because of a pre-existing $C a \mathrm{~F}_{1}$ overturned limb. We consider this unlikely based on the evidence that the rotational high-strain history cannot pre-date $C a \mathrm{D}_{2}$. Both $C a \mathrm{~F}_{1}$ and $C a \mathrm{~F}_{1}$ are rotated into the Arthur Lineament high-strain zone by the same amount and at the same position. Thus, the rotational strain must have formed during $C a \mathrm{D}_{2}$. The regional scale of the overturned limb (more than $60 \times 7 \mathrm{~km}$ ) and its close spatial relationship to the Arthur Lineament argues for a close genetic link of the overturned limb to the most intense event within the lineament.

In the Reece Dam area the $C a \mathrm{D}_{2}$-related features change orientation from Domain S1 to S2 (Figure 8b). Unlike the changes in orientation of the $C a \mathrm{D}_{1^{-}}$and $C a \mathrm{D}_{2}$-related features between the low- and high-strain domains due to shear-related rotation, stereonet analysis indicates the change in orientation from Domain S1 to S2 is the result of refolding by the $C a \mathrm{D}_{3}, D e \mathrm{D}_{4}$ and $D e \mathrm{D}_{5}$ events. Rotation of the eastern domain $\mathrm{CaS}_{2}$ and $\mathrm{Ca \textrm {L } _ { 0 2 }}$ about the $D e \mathrm{~F}_{5}$ axis $\left(30^{\circ} / 130^{\circ}\right), 50^{\circ}$ in an anticlockwise direction (looking down plunge), changes the $\mathrm{CaS}_{2}$ orientation from $45^{\circ} / 150^{\circ}$ to $55^{\circ} / 090^{\circ}$ and the $C a \mathrm{~L}_{02}$ orientation from $25^{\circ} / 230^{\circ}$ to $15^{\circ} / 020^{\circ}$. This angle corresponds to the

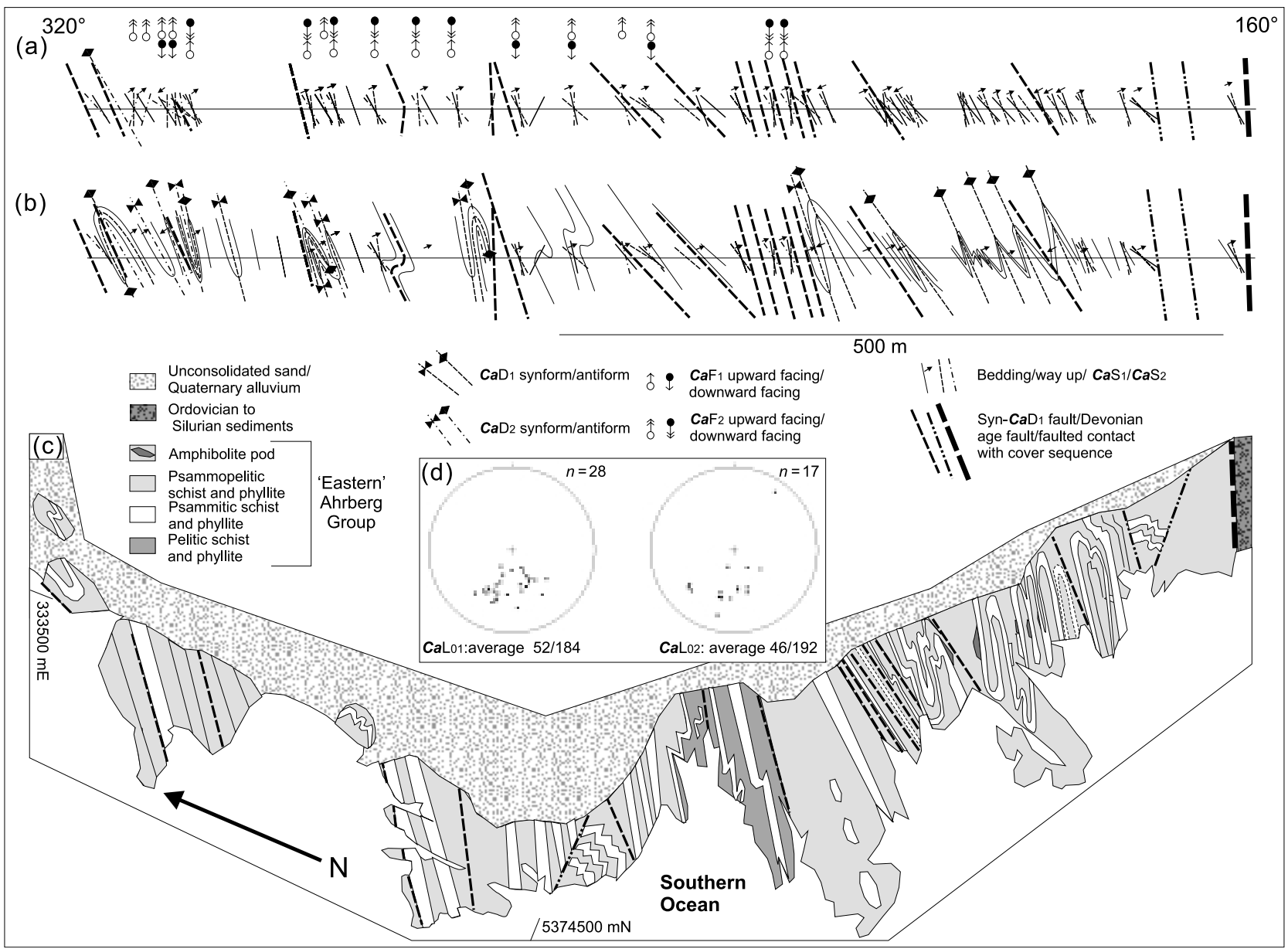

Figure 12 Structural style of the core of the Arthur Lineament on the west coast of Tasmania, north of Granville Harbour (333925 $\mathrm{mE}, 5374120 \mathrm{mN}$ to $333515 \mathrm{mE}, 5375000 \mathrm{mN}$ ). See Figure 2 for location. (a) Cross-section illustrating structural data for the core of the Arthur Lineament, west coast section. (b) Interpretive cross-section for the area. (c) Simplified geological map of the section. (d) Stereographic projections of $C a \mathrm{~L}_{01}$ and $C a \mathrm{~L}_{02}$ lineations for the area showing their predominantly moderate plunge to the south. 
refolding caused by the $D e \mathrm{~F}_{5}$ event. $C a \mathrm{D}_{1}$ - and $C a \mathrm{D}_{2}$-related faulting and shearing in Domain S2 are $\mathrm{CaS} 1^{-}$and $\mathrm{CaS}_{2-}$ parallel, respectively, and also differ in orientation between Domains S1 and S2 due to rotation caused by subsequent refolding.

The Corinna area to the west of the Arthur Lineament is dominated by the $C a \mathrm{D}_{3}$ event. Although this study only includes the 'western' Ahrberg Group and Rocky Cape Group correlates to the west of the southern Arthur Lineament, work by Everard et al. (1996) indicates that this event is also prominent in the Trowutta area to the west of the Arthur Lineament further north. In the Corinna area, the style and orientation of the $\mathrm{CaF}_{3}$ folding indicate east-west compression and a west-over-east transport direction. This suggests a change in the structural regime, probably during the Late Cambrian, the significance of which is poorly understood.

\section{CONCLUSIONS}

Gee (1967a, 1977) interpreted the most intense, widespread deformation in northwestern Tasmania $\left(\mathrm{CaD} \mathrm{D}_{2}\right.$ in this paper) to be the earliest event, during which the Rocky Cape Group and the Burnie Formation were transported to the southeast and deformed against the Precambrian Tyennan Nucleus. Further to this Gee (1967a) grouped $\mathrm{CaD}$ and $\mathrm{Ca} \mathrm{D}_{3}$, and concluded that this event (his D1) produced shallow plunging folds trending northeast-southwest $\left(\mathrm{CaF} \mathrm{F}_{3}\right.$ in this paper) and recumbent folds $\left(\mathrm{CaF} \mathrm{F}_{2}\right.$ in this paper) in conjunction with the metamorphism defining the Arthur Lineament.

We interpret the $C a \mathrm{D}_{1}$ event (not described by Gee 1967a, b, 1977) to represent major shearing producing isoclinal folds and bedding-parallel thrust faults. $C a \mathrm{D}_{2}$ produced widespread areas of low and high strain. The change in

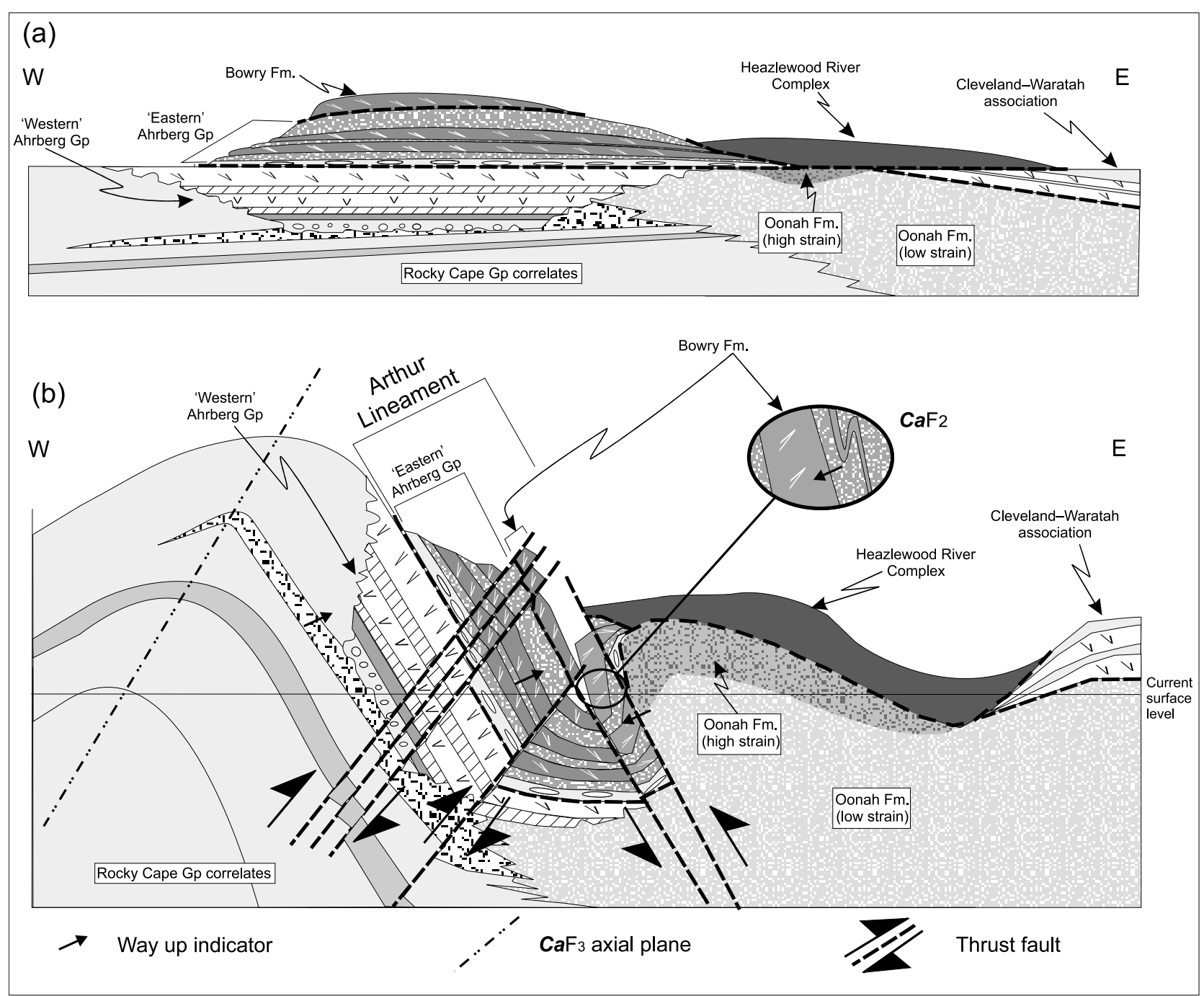

Figure 13 Schematic sections showing the formation of the southern Arthur Lineament. (a) Emplacement of allochthonous and parautochthonous slices over subhorizontal Neoproterozoic succession during the $C a \mathrm{D}_{1}$ and $C a \mathrm{D}_{2}$ events. (b) Intense folding and faulting $\left(\mathrm{CaD}_{3}\right)$ leading to the present-day linear expression of the Arthur Lineament. See Figure 2 for legend. Heazlewood River Complex is an allochthonous ultramafic complex. Cleveland-Waratah association consists of tholeiitic basalts and marine sediments, and is interpreted to be part of an oceanic forearc that was obducted onto western Tasmania in the late Early or early Middle Cambrian (Berry \& Crawford 1988; Brown \& Jenner 1988; Seymour \& Calver 1995). West dipping faults in (b) are interpreted to be syn-Ca $\mathrm{D}_{3}$, eastdipping thrust faults are late, age uncertain. 


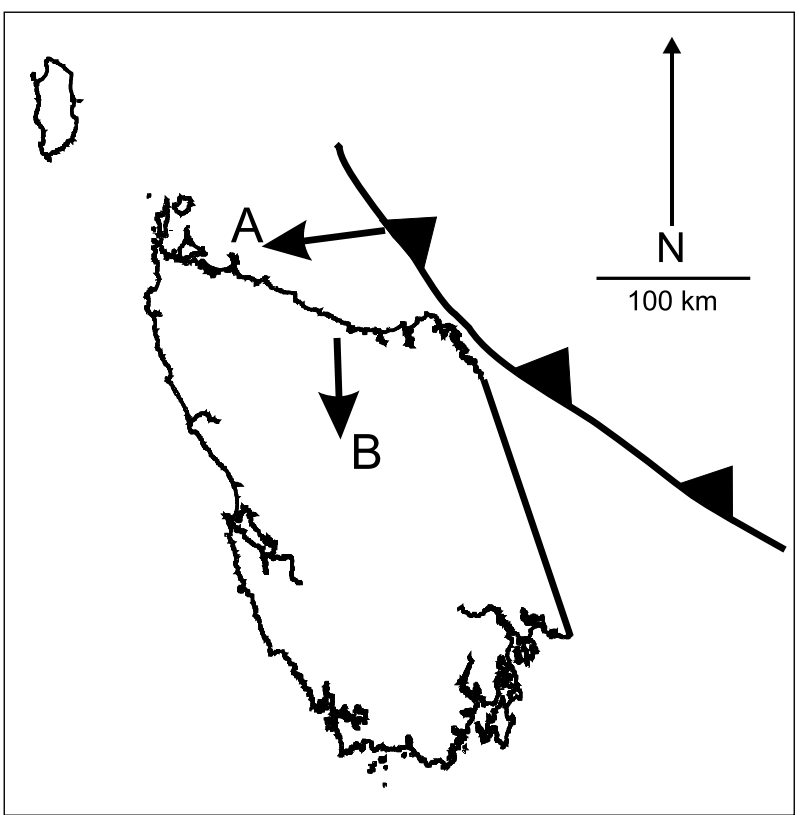

Figure 14 Schematic diagram of Tasmania during the westdirected obduction of oceanic forearc in the late Early or early Middle Cambrian. A, transport direction based on hornblende mylonite at the base of the ophiolite bodies (Berry 1989); B, transport direction inferred from the Arthur Lineament and Port Davey Metamorphic Complex.

style and orientation of $\mathrm{Ca \textrm {F } _ { 2 }}$ from areas of low to high $\mathrm{Ca \textrm {D } _ { 2 }}$ strain suggests a major component of rotational strain. The rotation of $\mathrm{CaF}_{2}$ into the Arthur Lineament is interpreted to result from a north-south stretching direction along a shallowly dipping detachment, with some evidence supporting south-southwest-directed transport. This resulted in the juxtaposition of the allochthonous Bowry Formation and parautochthonous 'eastern' Ahrberg Group with the 'western' Ahrberg Group and Oonah Formation.

At the conclusion of the $C a \mathrm{D}_{2}$ event, the lineament is interpreted to have been a subhorizontal feature, with the various slices being vertically stacked (Figure 13a). The interpretation of a shallowly dipping detachment is largely based on the Somerset - Doctors Rocks area. Where $C a \mathrm{D}_{3}$ is weak (Domains N1 and N3), $C a \mathrm{D}_{2}$ structures are subhorizontal. In this area, $\mathrm{CaS}_{2}$ dips gently to the south and southeast, and $\mathrm{CaF}$ fold axes have gentle plunges, to the east and west (in Domain N1) and to the south (in Domain N3). There is no evidence for a later structure that could have rotated this foliation from an original steep dip. However, where $C a \mathrm{D}_{3}$ is more strongly developed (Domain $\mathrm{N} 2$, and the southern Arthur Lineament), the $C a \mathrm{D}_{2}$ features are moderately to steeply dipping. The transition from a subhorizontal structure to an east-dipping structure along most of the Arthur Lineament probably occurred as a result of the folding and thrusting during $C a \mathrm{D}_{3}$, resulting in the present linear expression of the structure (Figure 13b). During the Middle Devonian, further folding resulted in localised dome-and-basin style folds and additional variability in the trend of the Arthur Lineament.

The detailed structural studies in the Arthur Lineament indicate a strong north-south stretching direction on the detachments during the Cambrian. A similar stretching direction occurs in the allochthonous high-strain rocks of the Ulverstone Metamorphic Complex, $20 \mathrm{~km}$ to the east. Reed (2001) has recognised evidence for very early (syn- $D_{1}$ ) thrusting to the southeast in the Badger Head Complex. Meffre et al. (2001) have reported Cambrian south-directed transport on mylonites in the Port Davey Metamorphic Complex. All these structures have been correlated with arc-continent collision and ophiolite obduction (Berry 1994). The hornblende mylonites exposed within metres of the base of the ophiolite sheets show a west- to southwest-directed transport direction when reoriented to a preDevonian orientation (Berry 1989). These hornblende mylonites formed at a high temperature $\left(>700^{\circ} \mathrm{C}\right)$ based on mineral chemistry. In contrast, the structures in the Arthur Lineament formed at greenschist to low amphibolite facies conditions. We interpret the difference in these directions as representing a change in ophiolite transport direction (Figure 14) from an early vector towards the west to a southdirected transport in the later stages of the emplacement onto Tasmania.

\section{ACKNOWLEDGEMENTS}

This research was carried out with the support of a postgraduate Tasmanian Government Mining Scholarship, together with a University of Tasmania Faculty of Science and Engineering Scholarship. We thank Goldstream Pty Ltd, Australian Bulk Minerals (Savage River Mine) and Cominex Pty Ltd for logistic support during fieldwork, Hydro Tasmania for access to Reece Dam and spillway, and Tony Crawford for helpful comments. Mike Hall and Nic Turner are thanked for constructive reviews.

\section{REFERENCES}

Adams C. J., Black L. P., Corbett K. D. \& Green G. R. 1985 Reconnaissance isotopic studies bearing on the tectonothermal history of Early Palaeozoic and Late Proterozoic sequences in Western Tasmania. Australian Journal of Earth Sciences 32, 7-36.

BERRY R. F. 1989. Microstructural evidence for a westward transport direction during middle Cambrian obduction in Tasmania Geological Society of Australia Abstracts 24, 8-9.

BERRY R. F. 1994. Tectonics of western Tasmania: Late Precambrian Devonian. Geological Society of Australia Abstracts 39, 6-8.

BERRY R. F. \& CRAWFORD A. J. 1988. The tectonic significance of Cambrian allochthonous mafic-ultramafic complexes in Tasmania. Australian Journal of Earth Sciences 35, 523-533.

Brown A. V. 1989. Eo-Cambrian-Cambrian. In: Burrett C. F. \& Martin E. L. eds. Geology and Mineral Resources of Tasmania, pp. 47-84. Geological Society of Australia Special Publication 15.

Brown A. V., Calver C. R., Corbett K. D., Forsyth S. M., Goscombe B. A., Green G. R., McLenaghan M. P., Pemberton J. \& Seymour D. B. 1995. Geological Atlas 1:250 000 Digital Series. Tasmanian Geological Survey, Hobart.

Brown A. V. \& Jenner G. 1988. Tectonic implications of the reinterpretation of Eocambrian-Cambrian mafic volcanic and associated ultramafic rocks, western Tasmania. In: Turner N. J. ed. The Geology and Evolution of the Latest Precambrian to Cambrian Rocks in the Western Tasmania Terrane, pp. 23-25. Geological Society of Australia, Tasmanian Division, Hobart.

CAlver C. R. \& Walter M. R. 2000. The late Neoproterozoic Grassy Group of King Island, Tasmania: correlation and palaeogeographic significance. Precambrian Research 100, 299-312. 
Cox S. F. 1989. Cape Wickham. In: Burrett C. F. \& Martin E. L. eds. Geology and Mineral Resources of Tasmania, pp. 154-181. Geological Society of Australia Special Publication 15.

CRAWFORD A. J. 1992. Geochemistry and implications of mafic metavolcanics in the Corinna - Savage River area. In: Turner N. J. ed. Corinna 1:50000 Geological Map: Field Guide to Selected Rock Exposures, pp. 27-37. Tasmania Department of Mines Report 1992/06.

CRAWFord A. J. \& BerRY R. F. 1992. Tectonic implications of Late Proterozoic - Early Palaeozoic igneous rock associations in western Tasmania. Tectonophysics 214, 37-56.

Dewey J. F., Holdsworth R. E. \& Strachan R. A. 1998. Transpression and transtension zones. In: Holdsworth R. E., Strachan R. A. \& Dewey J. F. eds. Continental Transpressional and Transtensional Tectonics, pp. 1-14. Geology Society of London Special Publications 135.

Everard J. L., Seymour D. B. \& Brown A. V. 1996. Geological Atlas 1:50 000 Series, Sheet 27 (7915N), Trowutta. Department of Environment and Land Management, Hobart.

GeE R. D. 1967a. The Proterozoic rocks of the Rocky Cape Geanticline. In: The Geology of Western Tasmania-a Symposium. University of Tasmania, Hobart (unpubl.).

GeE R. D. 1967b. The tectonic evolution of the Rocky Cape Geanticline in northwest Tasmania. PhD thesis, University of Tasmania, Hobart (unpubl.).

GeE R. D. 1977. Burnie, Tasmania, Geological Atlas 1 Mile Series Explanatory Report, Sheet 22(8015N). Tasmania Department of Mines, Hobart.

Gee R. D., Gulline A. B. \& Bravo A. P. 1967. Burnie, Tasmania, Geological Atlas 1 Mile Series, Sheet 28(8015N). Tasmanian Department of Mines, Hobart.

MefFre S., Berry R. F. HALL M. \& MCNeILl A. 2001. The structural style of Cambrian metamorphic complexes in Tasmania: SW Tasmania examples. Geological Society of Australia Abstracts 64, 118-120.

Passchier C. W. \& Trouw R. A. J. 1996. Microtectonics. Springer-Verlag, Berlin.

ReED A. R. 2001. Structure and setting of Proterozoic and Palaeozoic rocks in the Tamar region, northern Tasmania. Geological Society of Australia, Tectonics and Structural Geology Specialist Group Field Guide 9
RIDLEY J. \& CASEY M. 1989. Numerical modelling of folding in rotational strain histories: strain regimes expected in thrust belts and shear zones. Geology 17, 875-878.

SEymour D. B. \& CALver C. R. 1995. Explanatory notes for the Time-Space Diagram and Stratotectonic Elements Map of Tasmania. Tasmanian Geological Survey Record 1995/01.

SpRY A. H. 1957a. Lower Pieman Hydro-Electric Development: geology of part of the lower Pieman River. Report to the Hydro-Electricity Commission Tasmania (unpubl.).

Spry A. H. 1957b. The Precambrian rocks of Tasmania, Part 1 , dolerites of the north-west coast of Tasmania. Papers and Proceedings of the Royal Society of Tasmania 91, 81-93.

SPRY A. H. 1964. Precambrian rocks of Tasmania, Part VI, the Zeehan - Corinna area. Papers and Proceedings of the Royal Society of Tasmania 98, 23-48.

Turner N. J. 1989. The Precambrian. In: Burrett C. F. \& Martin E. L. eds. Geology and Mineral Resources of Tasmania, pp. 5-46. Geological Society of Australia Special Publication 15.

TURNER N. J. 1992. Corinna 1:50 000 geological map: Field guide to selected rock exposures. Tasmania Department of Mines Report 1993/06.

Turner N. J., Black L. P. \& Kamperman M. 1998. Dating of Neoproterozoic and Cambrian orogenies in Tasmania. Australian Journal of Earth Sciences 45, 789-806.

Turner N. J. \& Bottrill R. S. 2001. Blue amphibole, Arthur Metamorphic Complex, Tasmania: composition and regional tectonic setting. Australian Journal of Earth Sciences 48, 167-181.

Turner N. J., Brown A. V., McClenaghan M. P. \& Soetrisno I. R. 1991. Geological atlas 1:50 000 Series, Sheet 43 (7914N), Corinna. Department of Resources and Energy, Hobart.

Turner N. J. \& Crawford A. J. 1993. General features and chemical analyses of mafic and other rocks, Corinna geological map quadrangle. Mineral Resources Tasmania Report 1993/23.

Williams E., McClenaghan M. P. \& Collins P. L. F. 1989. Mid-Palaeozoic deformation, granitoids and ore deposits. In: Burrett C. F. \& Martin E. L. eds. Geology and Mineral Resources of Tasmania, pp. 239-292. Geological Society of Australia Special Publication 15.

Received 7 November 2000; accepted 30 July 2001 